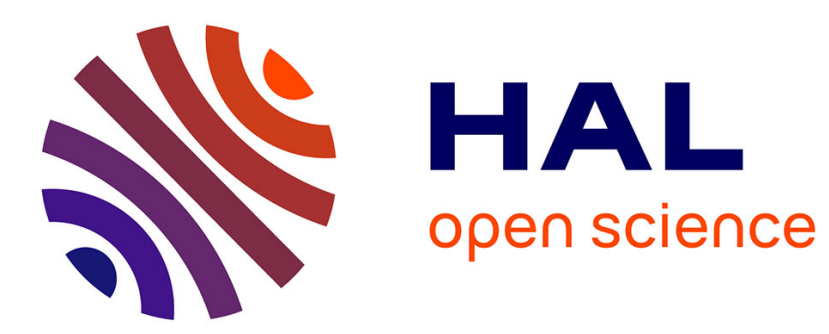

\title{
Synthesis and Modification of Alternating Copolymers Based on Vinyl Ethers, Chlorotrifluoroethylene, and hexafluoropropylene
}

\author{
David Valade, Frédéric Boschet, Bruno Ameduri
}

\section{- To cite this version:}

David Valade, Frédéric Boschet, Bruno Ameduri. Synthesis and Modification of Alternating Copolymers Based on Vinyl Ethers, Chlorotrifluoroethylene, and hexafluoropropylene. Macromolecules, 2009, 42, pp.7689-7700. 10.1021/ma900860u . hal-00447589

\author{
HAL Id: hal-00447589 \\ https://hal.science/hal-00447589
}

Submitted on 18 Jan 2010

HAL is a multi-disciplinary open access archive for the deposit and dissemination of scientific research documents, whether they are published or not. The documents may come from teaching and research institutions in France or abroad, or from public or private research centers.
L'archive ouverte pluridisciplinaire HAL, est destinée au dépôt et à la diffusion de documents scientifiques de niveau recherche, publiés ou non, émanant des établissements d'enseignement et de recherche français ou étrangers, des laboratoires publics ou privés. 


\section{Synthesis and Modification of Alternating Copolymers}

\section{Based on Vinyl Ethers, Chlorotrifluoroethylene, and}

\section{Hexafluoropropylene.}

David Valade, Frédéric Boschet, Bruno Améduri

Institut Charles Gerhardt, Ingénierie et Architectures Macromoléculaires, UMR CNRS 5253, Ecole

Nationale Supérieure de Chimie de Montpellier, 8 Rue de l'Ecole Normale, 34296 Montpellier, France

* To whom correspondence should be addressed, bruno.ameduri@enscm.fr

(Dedicated to Prof. Georgi Kostov on the occasion of his $65^{\text {th }}$ birthday) 


\title{
Synthesis and Modification of Alternating Copolymers
}

\section{Based on Vinyl Ethers, Chlorotrifluoroethylene, and}

\section{Hexafluoropropylene.}

David Valade, Frédéric Boschet, Bruno Améduri

Institut Charles Gerhardt, Ingénierie et Architectures Macromoléculaires, UMR CNRS 5253, Ecole

Nationale Supérieure de Chimie de Montpellier, 8 Rue de l'Ecole Normale, 34296 Montpellier, France

* To whom correspondence should be addressed, bruno.ameduri@enscm.fr

(Dedicated to Prof. Georgi Kostov on the occasion of his $65^{\text {th }}$ birthday)

\begin{abstract}
Fluorinated copolymers bearing ammonium groups were prepared by radical copolymerization of fluorinated olefins (chlorotrifluoroethylene, hexafluoropropylene) with different vinyl ethers (2-chloroethyl, cyclohexyl, $n$-butyl, and ethyl vinyl ethers) followed by the cationization of these copolymers with trimethylamine. Copolymers were obtained in high yield (generally $>85 \%$ ), with molecular weights ranging from 8,000 to 25,000 g.mol ${ }^{-1}$. From elemental analysis, ${ }^{1} \mathrm{H}$ and ${ }^{19} \mathrm{~F}$ NMR spectroscopy, the alternating structure of these polymers was confirmed. The chemical modification of these copolymers consisted in a two-step reaction: (i) the replacement of the chlorine atom by an iodine atom followed by (ii) the substitution of the halogen atom by the trimethylamine into a quaternary
\end{abstract}


ammonium. The resulting copolymers were characterized with the usual techniques to assess their compositions and structures. Their thermal analyses, in dynamic mode, under air, showed decomposition temperatures $\left(T_{\mathrm{d}, 10 \%}\right)$ higher than $200{ }^{\circ} \mathrm{C}$. Electrochemical properties of some of these polymers were also studied, showing ionic exchange capacities (IEC) ranging from 0.50 to 0.75 meq. $\mathrm{g}^{-1}$ (theoretical IEC up to 3.63 meq.g ${ }^{-1}$ ), and water uptake of $13-25 \%$

KEYWORDS. Fluoropolymers, solid alkaline fuel cell, alternating copolymerization, microstructure, quaternary ammonium, vinyl ethers, chlorotrifluoroethylene, hexafluoropropylene

INTRODUCTION. Among the different types of fuel cells, solid alkaline fuel cells (SAFCs) appear as an attractive solution to the energy crisis, global warming/green energy and the development of new sources of energy. ${ }^{1,2}$ SAFCs are among the most recent fuel cells technology, combining the best of both alkaline batteries and solid polymer electrolyte membranes for fuel cells (PEMFCs). In contrast to other fuel cells, SAFCs, which use anion-exchange membranes, do not require noble metals $(\mathrm{Pt}, \mathrm{Ru} . .$.$) as$ catalysts to function, which is one of the main drawbacks for the commercialization of PEMFCs based on proton-exchange membranes. ${ }^{1}$ Nevertheless, SAFCs are still in the early stages of development especially for membrane-electrodes assembly (MEA). To achieve a good MEA, a binder is required to strengthen the interface between the membrane and the electrodes.

Within this research, our goal is to prepare a polymeric binder endowed with a good conductivity, a high ionic exchange capacity, both water and fuels (such as methanol, ethylene glycol...) insolubility, and organic medium solubility (dimethylsulfoxide, dimethylformamide) for fuel cell implementation reasons.

Fluoropolymers exhibit remarkable properties, ${ }^{3-7}$ such as chemical resistance (to acids, bases, organic solvents), low dielectric constants and dissipation factors, hydrophobic and oleophobic properties, 
excellent weathering, and interesting surface properties. Hence, these high value-added-materials can find applications in many fields of high technology such as aeronautics, ${ }^{8}$ microelectronics,${ }^{9}$ optics, ${ }^{10,11}$ textile finishing, ${ }^{12}$ in the nuclear industry, ${ }^{13}$ in paints and coatings ${ }^{14}$ and microlithography. ${ }^{15}$

Chlorotrifluoroethylene (CTFE) was first polymerized in 1934 (its polymerization was patented in 1937). ${ }^{16}$ It yields hydrophobic polymers with chemical and thermal resistance along with good mechanical properties. Also, the poly(CTFE) polymers presently marketed by Honeywell, under the Aclar ${ }^{\circledR}$ trademark, have remarkable gas-barrier properties. ${ }^{17}$

Since their discovery in 1971 by Tabata and Du Plessis ${ }^{18}$, poly(chlorotrifluoroethylene-alt-vinyl ether)s copolymers have received much industrial attention in the domain of paints and coatings ${ }^{19-24}$ (i.e. LUMIFLON® marketed by the Asahi Glass Co. Ltd ${ }^{25-29}$. These applications arise essentially from their excellent resistance to ageing and their solubility ${ }^{19}$. Although tetrafluoroethylene (TFE) is sometimes preferred to chlorotrifluoroethylene (CTFE) as a precursor of fluorinated materials just like poly(TFE-alt-VE) copolymers (Zeffle ${ }^{\circledR}$ paints produced by Daikin Company) mainly because of the presence of a chlorine atom instead of a perfluorinated chain. CTFE can also enhance the solubility when introduced as comonomer in alternating copolymers, in the contrast to the poly(CTFE) homopolymer that is only soluble in 1,3-dichlorobenzenetrifluoride at $150{ }^{\circ} \mathrm{C} .^{30}$

As with ethylene $\mathrm{e}^{31-39}$ (HALAR ${ }^{\circledR}$ from Solvay-Solexis), propylene ${ }^{40-43}$, isobutylene ${ }^{41,42,44,45}$, [1(fluoromethyl)vinyl]benzene ${ }^{46}$, or vinyl acetate ${ }^{47-49}$, which had led to statistic copolymers of low CTFE content (compared to that of the feed), CTFE can copolymerize with vinyl ethers to form alternated copolymers $^{18,19,24,50-52}$. This particularity arises from the acceptor character of CTFE $(e=1.56)$ opposed to the donor character of the vinyl ethers $(-2.0<e<-1.5)$ which do not homopolymerize under radical polymerization $^{53,54}$. Some studies have described this alternating copolymerization as a propagation by transfer of charges between acceptor and donor complexes, ${ }^{55,56}$. However, it is commonly accepted that it results from a traditional mechanism of propagation between free monomers having a different polarity. ${ }^{50-52,57,58}$ 
However, the literature does not report any work on the radical copolymerization of hexafluoropropylene (HFP) with vinyl ethers. In addition, to the best of our knowledge, copolymers based on CTFE and vinyl ether have never been reported to be involved in an ionomer membrane and it was of interest to attempt that challenge. Interestingly, 2-chloroethylvinyl ether (CEVE) should allow a further introduction of ionic groups on the polymer chain. Originally, using this monomer, poly(CTFEalt-VE) copolymers were used as functional materials. ${ }^{23}$ Cyclohexylvinyl ether (CHVE), butylvinyl ether (BVE), and ethylvinyl ether (EVE) have been employed to change the solubility of the resulting polymer and to control the amount of CEVE incorporated and by the means to control the amount of ionic sites. The objectives of this article are, first, to synthesize and to characterize the poly(CTFE-altVE), poly(HFP-alt-VE), and poly[(CTFE-alt-VE)-co-(HFP-alt-VE)] copolymers, to enable their chemical modification into ionomers as original binders for solid alkaline fuel cell (SAFC), and finally to assess their electrochemical and thermal properties.

\section{EXPERIMENTAL}

Materials. Tert-butylperoxypivalate (TBPPi, Trigononx ${ }^{\circledR}$ 25-C75, $75 \mathrm{wt} \%$ solution in isododecane) and sodium persulfate $\left(\mathrm{Na}_{2} \mathrm{~S}_{2} \mathrm{O}_{8}\right.$, purity $\left.>99 \%\right)$ were kindly provided by Akzo Nobel (Compiègne, France). Chlorotrifluoroethylene (CTFE), hexafluoropropylene (HFP), and 1,1,1,3,3-pentafluorobutane $\left(\mathrm{C}_{4} \mathrm{~F}_{5} \mathrm{H}_{5}\right)$ were kindly provided by Solvay S.A. (Tavaux, France \& Bruxelles, Belgium) and were used as received. The different vinyl ethers (cylcohexylvinyl ether (CHVE), chloroethylvinyl ether (CEVE), ethylvinyl ether (EVE), and butylvinyl ether (BVE), all purities >98\%), water (HPLC grade), methanol (analytical grade), tetrahydrofuran (THF, analytical grade), potassium carbonate $\left(\mathrm{K}_{2} \mathrm{CO}_{3}\right.$, puriss), and trimethylamine (TMA, purum) were purchased from Sigma-Aldrich (Saint Quentin-Fallavier, France). Deuterated solvents for the NMR were purchased from Euroiso-top (Grenoble, France) (purity $>99.8 \%$ ).

Radical copolymerization of fluoroolefins with vinyl ethers. As CTFE and HFP are gases, the reactions were carried in a Hastelloy autoclave Parr system equipped with a manometer, a rupture disk (3000 PSI), inlet and outlet valves and a magnetic stirrer. Prior to reaction, the autoclave was 
pressurized with 30 bars (i.e. $430 \mathrm{PSI}$ ) of nitrogen to check for eventual leaks. The autoclave was then conditioned for the reaction with several nitrogen/vacuum cycles $\left(10^{-2} \mathrm{mbar}\right)$ to remove any traces of oxygen. The liquid phase was first introduced via a funnel, and then the gases were inserted by double weighing (i.e. the difference of weight before and after filling the autoclave with the gas). Then, the autoclave was placed into an oil bath with a vigorous magnetic stirring. After an initial increase of the internal pressure due to the increasing temperature, the pressure dropped by consumption of the gaseous monomer to produce a polymer in the liquid phase. After the reaction was completed, the product was dried under vacuum $\left(10^{-2}\right.$ mbar $)$ at $70{ }^{\circ} \mathrm{C}$ until constant weight.

\section{Poly(CTFE-alt-VE) alternated copolymers and terpolymers (P1, P2, P4, ,P7, and P8 in Tables 1}

and 2). The reaction was carried out in 1,1,1,3,3-pentafluorobutane as the solvent in the presence of tertbutylperoxypivalate (TBPPi, $1 \mathrm{~mol} \%$ vs. monomers) as the initiator, and potassium carbonate ( 3 mol\% vs. CHVE) to prevent the cationic homopolymerization of CHVE, and the formation of the acetal from the vinyl ether. ${ }^{59}$ The reaction was allowed to proceed at $68^{\circ} \mathrm{C}$ for 12 hours showing a drop of pressure as the CTFE was reacting. After the reaction, the autoclave was cooled in an ice bath, vented from the unreacted gases, and opened. After the distillation of the solvent, the product was precipitated from methanol to remove any remaining solvents, monomers, potassium carbonate, initiators and oligomers. The polymer, obtained as a white powder, was then dried in a vacuum $\left(10^{-2} \mathrm{mbar}\right)$ oven at $50{ }^{\circ} \mathrm{C}$ until constant weight. For the P2 copolymer, the reaction was carried out in deionized water instead, in the presence of 1,1,1,3,3-pentafluorobutane (3 wt.\%) to favor the dispersion of the fluorinated monomer in the aqueous phase. The copolymerization was initiated by $\mathrm{Na}_{2} \mathrm{~S}_{2} \mathrm{O}_{8}(1 \mathrm{~mol} . \%)$, and $\mathrm{K}_{2} \mathrm{CO}_{3}$ was also used.

Example: Synthesis of P4. CEVE (18.1 g, $0.17 \mathrm{~mol})$ TBPPi $\left(0.79 \mathrm{~g}, 3.4 .10^{-3} \mathrm{~mol}\right), \mathrm{K}_{2} \mathrm{CO}_{3}(0.68 \mathrm{~g}$, $\left.5.10^{-3} \mathrm{~mol}\right)$, and 1,1,1,3,3-pentafluorobutane $(80 \mathrm{~mL})$ were introduced in the autoclave. Then CTFE $(20 \mathrm{~g}, 0.17 \mathrm{~mol})$ was added. The autoclave was heated at $68{ }^{\circ} \mathrm{C}$ for $15 \mathrm{hrs}$. After precipitation of the crude product in methanol and drying, the yield was assessed $(80 \%)$ and the copolymer was 
characterized (SEC indicated a $\mathrm{M}_{\mathrm{n}}$ of 20,600 g. $\mathrm{mol}^{-1}$ and a PDI of 2.4, and the alternating structure was demonstrated by NMR and elemental analysis).

\section{Poly(HFP-alt-VE) copolymers (P5) and poly[(CTFE-alt-VE)-co-(HFP-alt-VE)] terpolymers (P3,} P6, P9, P10, P11, and P12 in Tables 1 and 2). As above, the polymerization was achieved in an autoclave in the presence of tert-butyl peroxypivalate (TBPPi, $1 \%$ vs. monomers) and 1,1,1,3,3pentafluorobutane as the initiator and the solvent, respectively. $\mathrm{K}_{2} \mathrm{CO}_{3}$ was also introduced ( 3 mol\% vs. VE) prior to reaction. Fluorinated monomers were introduced in slight excess to favor the complete consumption of the vinyl ether. In the case of $\mathrm{P} 3$, the reaction was carried out in the same conditions as for $\mathrm{P} 2$, i.e. in deionized water with 3 wt.\% of $\mathrm{C}_{4} \mathrm{~F}_{5} \mathrm{H}_{5}$, initiated by $\mathrm{Na}_{2} \mathrm{~S}_{2} \mathrm{O}_{8}$ ( 1 mol.\% vs monomers) in the presence of $\mathrm{K}_{2} \mathrm{CO}_{3}$ ( 3 mol.\% vs. vinyl ethers). The polymerization was allowed to occur at $68{ }^{\circ} \mathrm{C}$ for 15 hours. The same procedure as above was used for the purification of poly[(CTFE-alt-VE)-co-(HFPalt-VE)] terpolymers.

\section{Modifications of copolymers}

Iodination reaction (Table 3). The copolymer was dissolved in acetone in a single-neck round bottom flask equipped with a magnetic stirrer and a condenser. Then, three equivalents of sodium iodide were introduced in the flask and the reaction was allowed to reflux for 7 days. After the reaction and cooling to room temperature, the produced salts (sodium chloride and sodium iodide) were filtered. Then, the polymer was precipitated from methanol and dried under vacuum at $50{ }^{\circ} \mathrm{C}$ for 4 hours to produce a white powder.

Amination reaction. The copolymer was first dissolved in acetone in a single-neck round bottom flask equipped with a magnetic stirrer and a condenser. Then, 3 equivalents (vs. iodine sites) of triethylamine (TMA) were introduced in the flask and the reaction was allowed to pursue at $40{ }^{\circ} \mathrm{C}$ for 48 hours. The copolymer which changed solubility (from non-polar towards polar solvents) was then dried by evaporation of the amine and acetone, resulting in a crystalline powder. The yield was quantitative.

Counter-ion exchange. To replace the iodide counter-anions by hydroxides, the polymer was immersed in a $1 \mathrm{M}$ solution of sodium hydroxide for 24 hours under a vigorous stirring. The procedure 
was repeated another time to reach complete conversion, and the polymer was then rinsed several times with water (HPLC quality), and dried under vacuum at $50{ }^{\circ} \mathrm{C}$ for 3 hours.

Preparation of membranes. The membranes were cast from a polymer solution in DMSO (ca. $1 \mathrm{~g}$ of polymer for $2 \mathrm{~g}$ of DMSO) onto a glass substrate followed by a vacuum drying at $50{ }^{\circ} \mathrm{C}$ for $24 \mathrm{hrs}$. The membranes were then removed from the substrate by immersion in water. Most products exhibited good casting properties (homogeneous surface after drying and immersion). These membranes were soft but shrank, and several of them became brittle when drying.

\section{Characterizations}

SEC. Size exclusion chromatography (SEC) measurements were conducted on a Spectra-Physics apparatus equipped with two $5 \mu \mathrm{m}$ Mixed-C PL-gels columns (Polymer Labs), a SP8430 SpectraPhysics Refractive Index detector using THF as the eluent at $70{ }^{\circ} \mathrm{C}$ and a flow rate of $0.6 \mathrm{~mL} / \mathrm{min}$. Monodisperse polystyrene standards were used for the calibration.

NMR. The nuclear magnetic resonance (NMR) spectra were recorded on a Bruker AC 400 instrument, using deuterated chloroform, acetone, or dimethylsulfoxide as the solvent and tetramethylsilane (TMS) (or $\mathrm{CFCl}_{3}$ ) as the references for ${ }^{1} \mathrm{H}$ (or ${ }^{19} \mathrm{~F}$ ) nuclei. The experimental conditions for recording ${ }^{1} \mathrm{H}\left(\right.$ or $\left.{ }^{19} \mathrm{~F}\right)$ NMR spectra were as follows: flip angle $90^{\circ}$ (or $30^{\circ}$ ), acquisition time $4.5 \mathrm{~s}$ (or $0.7 \mathrm{~s}$ ), pulse delay $2 \mathrm{~s}$ (or 2 s), number of scans 128 (or 512), and a pulse width of $5 \mu$ s for ${ }^{19} \mathrm{~F} \mathrm{NMR.}$

The microstructures of the copolymers of the polymers were assessed by ${ }^{1} \mathrm{H}$ and ${ }^{19} \mathrm{~F}$ NMR spectroscopy. The absence of a signal at $-100 \mathrm{ppm}^{60}$ and $-127 \mathrm{ppm}^{61}$ on the ${ }^{19} \mathrm{~F}$ NMR spectra indicate the absence of CTFE-CTFE diads, which is considered as an evidence of the alternating structure of the CTFE with vinyl ethers. Vinyl ethers do not homopolymerize and thus no VE-VE diads could be observed. The measured chemical shifts assigned to vinyl ethers were in good agreement with previous works demonstrating the alternating structure of poly(CTFE-alt-VE) copolymers $^{51,52}$. Notice also that the NMR did not enabled us to make the difference between poly[(CTFE-co-HFP)-alt-VE] and poly[(CTFE-alt-VE)-co-(HFP-alt-VE)]. 
The copolymer composition was assessed from the ${ }^{1} \mathrm{H}$ and ${ }^{19} \mathrm{~F}$ NMR spectra (see supporting information). ${ }^{30,60-63}$

Elemental Analysis. The weight percentages of carbon and hydrogen atoms were assessed by elemental analysis at the CNRS - Service Central d'Analyse (Solaize, France) on a CH elemental analyzer equipped with a $\mathrm{CO}_{2} / \mathrm{H}_{2} \mathrm{O}$ infrared detector. Theoretical carbon and hydrogen compositions were calculated according to the polymer compositions assessed by ${ }^{1} \mathrm{H}$ and ${ }^{19} \mathrm{~F}$ NMR spectroscopy, and considering that co- or terpolymers have alternating structures (with $50 \%$ of fluorinated olefins and 50 $\%$ of vinyl ethers). Equations 1 and 2 were used to determine these theoretical values:

$$
\begin{aligned}
& \% \mathrm{C}=\sum_{\mathrm{i}}\left(\% \text { monomer }{ }_{\mathrm{i}} \times \frac{\mathrm{M}_{\mathrm{C}}}{\mathrm{M} \text { monomer }_{\mathrm{i}}}\right) \\
& \% \mathrm{H}=\sum_{\mathrm{i}}(\% \text { monomer } \\
& \mathrm{i}
\end{aligned}
$$

where $\%$ monomer $_{i}$ is the molar fraction of the monomer $i$ in the polymer, $M_{H}, M_{C}$ and $M_{\text {monomeri }}$ the respective molecular weights of the hydrogen and carbon atoms, and of the monomer.

Electrochemical properties. Water uptake was calculated at $25^{\circ} \mathrm{C}$ from the equation (3)

$$
\text { Water uptake }(\%)=\frac{\mathrm{m}_{\mathrm{h}}-\mathrm{m}_{\mathrm{s}}}{\mathrm{m}_{\mathrm{h}}} \times 100
$$

where $m_{h}$ and $m_{s}$ stand for the weight (in grams) of the hydrated membrane and of the dry membrane before immersion in water, respectively. Experimental ionic exchange capacity (IEC) was calculated at $25{ }^{\circ} \mathrm{C}$ from equation (4), as follows:

$$
\mathrm{IEC}_{\mathrm{exp}}=\frac{\left[\mathrm{Cl}^{-}\right] . \mathrm{V}}{\mathrm{m}_{\mathrm{s}}}
$$

where $\left[\mathrm{Cl}^{-}\right], \mathrm{V}$, and $\mathrm{m}_{\mathrm{s}}$ stand for the concentration of the exchange solution in anions $\mathrm{Cl}^{-}\left(\mathrm{mol}^{-1}\right)$, the volume of the exchange solution $(\mathrm{mL})$, and the weight of the dry membranes $(\mathrm{g})$, respectively. Membrane conductivity was determined from the following equation: 


$$
\sigma=\frac{l}{R S}
$$

where $l, \mathrm{R}$ and $\mathrm{S}$ represent the membrane thickness, the resistance measured by impedance spectroscopy, and the active surface of the membrane $\left(0.785 \mathrm{~cm}^{2}\right)$, respectively. The experimental device used for the resistance measurement was a Teflon ${ }^{\circledR}$ two-compartments cell clamping the humid membrane (100\% relative humidity). Each compartment was filled with liquid mercury and contained a platinum electrode.

TGA. Thermogravimetric analyses (TGA) were performed with a TGA 51 apparatus from TA Instruments, under air, at the heating rate of $10{ }^{\circ} \mathrm{C} \cdot \mathrm{min}^{-1}$ from room temperature up to a maximum of $500{ }^{\circ} \mathrm{C}$. The sample size varied between 10 and $15 \mathrm{mg}$.

DSC. Differential scanning calorimetry (DSC) measurements were conducted using a Perkin Elmer Pyris 1 apparatus. Scans were recorded at a heating rate of $20{ }^{\circ} \mathrm{C} \cdot \mathrm{min}^{-1}$ from -100 to $+100{ }^{\circ} \mathrm{C}$, and the cooling rate was $20^{\circ} \mathrm{C} \cdot \mathrm{min}^{-1}$. A second scan was required for the assessment of the $T_{g}$, defined as the inflection point in the heat capacity jump. The sample size was about $10 \mathrm{mg}$.

\section{RESULTS AND DISCUSSION}

\section{Synthesis and modification of Poly[(CTFE-alt-VE)-co-(HFP-alt-VE)] terpolymers.}

Terpolymerization. The radical copolymerizations of hexafluoropropylene (HFP) or chlorotrifluoroethylene (CTFE) with vinyl ethers (VEs), and the radical terpolymerization of CTFE with HFP and VE, initiated by tert-butylperoxypivalate (TBPPi), were achieved as depicted in Scheme $\mathbf{1}$ and in the experimental section. The radical copolymerization of CTFE with vinyl ethers is an exothermic reaction, and a rapid increase of pressure in the autoclave was observed, followed by a sharp drop of pressure.

Scheme 1. Radical copolymerization between fluorinated monomers (chlorotrifluoroethylene and hexafluoropropylene) and vinyl ethers. 
Several co- and ter-polymerizations were carried out with different molar feed compositions in CTFE, HFP, and VE (Table 2). HFP is usually incorporated to lower the crystallinity ${ }^{62}$ of the resulting copolymer, and to favor its film forming character. To the best of our knowledge, HFP has never been used in the copolymerization with vinyl ethers. The introduction of a second vinyl ether with CEVE allowed to decrease the amount of CEVE incorporated in the polymer, which was useful to further control the amount of ammonium groups in the final material. Besides, the introduction of cyclohexylvinyl ether (CHVE) led to a less hydrophilic polymer, limiting the risk of water-solubility of the final binder. On the other hand, the incorporation of butylvinyl ether (BVE) and ethylvinyl ether (EVE) can improve the mechanical properties necessary for the preparation of the membranes. ${ }^{23}$

The composition of the copolymers (Table 1) was determined by elemental analysis for the poly(CTFE-alt-VE) copolymers, and by ${ }^{19} \mathrm{~F}$ NMR spectroscopy for the poly[(CTFE alt-VE)-co-(HFPalt-VE)] terpolymers.

Table 1. Experimental conditions and compositions of the poly[(CTFE-alt-VE)co-(HFP-alt-VE] terpolymers assessed by elementary analysis, ${ }^{1} \mathrm{H}$ and ${ }^{19} \mathrm{~F}$ NMR spectroscopy.

\begin{tabular}{ccccccc|ccccccccc}
\hline \multirow{2}{*}{ Run\# } & \multicolumn{4}{c|}{ Feed composition (mol.\%) } & \multicolumn{3}{c}{ Terpolymer composition (mol.\%) } & \multicolumn{1}{c}{$\mathbf{t}_{\mathbf{R}}$} & \multicolumn{2}{c}{ T } & \multicolumn{1}{c}{ Yield } \\
& CTFE & HFP & CEVE & CHVE & EVE & BVE & CTFE & HFP & CEVE & CHVE & EVE & BVE & (h) & $\left({ }^{\circ}\right.$ C) & (\%) \\
\hline P1 & 50 & - & 20 & 30 & - & - & 50 & - & 12 & 38 & - & - & 15.0 & 68 & 83 \\
P2 & 50 & - & - & 50 & - & - & 50 & - & - & 50 & - & - & $3.5^{\mathrm{b}}$ & 68 & 74 \\
P3 & 10 & 40 & - & 50 & - & - & 15 & 35 & - & 50 & - & - & $0.8^{\mathrm{b}}$ & 74 & $44^{\mathrm{a}}$ \\
P4 & 50 & - & 50 & - & - & - & 50 & - & 50 & - & - & - & 15.0 & 68 & 80 \\
P5 & - & 50 & 50 & - & - & - & & 50 & 50 & - & - & - & 15.0 & 68 & 85 \\
P6 & 25 & 25 & 50 & - & - & - & 18 & 32 & 50 & - & - & - & 15.0 & 68 & 88 \\
P7 & 50 & - & - & - & - & 50 & 50 & - & - & - & - & 50 & 15.0 & 67 & 91 \\
P8 & 50 & - & - & - & 50 & - & 50 & - & - & - & 50 & - & 15.0 & 65 & 85 \\
P9 & 11 & 39 & - & - & - & 50 & 8 & 42 & - & - & - & 50 & 8.5 & 67 & 81
\end{tabular}




\begin{tabular}{lllllll|lllllllll} 
P10 & 11 & 39 & - & - & 50 & - & 10 & 40 & - & - & 50 & - & 4.0 & 67 & 89 \\
P11 & 50 & - & 30 & - & 20 & - & 50 & - & 26 & - & 24 & - & 15.0 & 68 & 91 \\
P12 & 50 & - & 30 & - & - & 20 & 50 & - & 27 & - & - & 23 & 15.0 & 68 & 93 \\
\hline
\end{tabular}

where the "P" prefix in the sample name stands for Polymer

Standard deviation on the determination of the copolymer composition by NMR: $\pm 2 \%$.

a. copolymerization interrupted after $45 \mathrm{~min}$ due to mechanical stirrer problem.

b. copolymerization in emulsion, the others were carried out in solution.

Solution copolymerization: solvent $=\mathrm{C}_{4} \mathrm{~F}_{5} \mathrm{H}_{5}$, initiator $=$ tertbutylperoxypivalate $(1 \mathrm{~mol} \%$ with respect to all monomers), potassium carbonate ( $3 \mathrm{~mol} \%$ vs. all vinyl ethers)

Emulsion copolymerization: solvent $=$ deionized water $+\mathrm{C}_{4} \mathrm{~F}_{5} \mathrm{H}_{5}(3 \mathrm{wt} . \%)$, initiator $=$ sodium persulfate ( 1 mol.\% with respect to all monomers), potassium carbonate ( 3 mol.\% vs. all vinyl ethers).

Copolymers and terpolymers of fluorinated olefins and vinyl ethers were obtained in high yields (close to $85 \%$ ), in agreement with the literature ${ }^{23,51,52}$. For some copolymerizations (P2, P3, and P10), the reactions were stopped after a short reaction time due to a large exotherm (resulting in a fast increase of the pressure in the autoclave).

Table 2. Properties and elemental analysis of the the poly[(CTFE-alt-VE)-co-(HFP-alt-VE)] terpolymers.

\begin{tabular}{|c|c|c|c|c|c|c|c|c|c|c|c|}
\hline \multirow[t]{2}{*}{ Run\# } & \multicolumn{2}{|c|}{$\% \mathrm{C}$} & \multicolumn{2}{|c|}{$\% \mathrm{H}$} & \multirow{2}{*}{$\begin{array}{c}M_{\mathrm{n}} \\
\left(\mathrm{g} \cdot \mathrm{mol}^{-1}\right)\end{array}$} & \multirow[t]{2}{*}{ PDI } & \multicolumn{3}{|c|}{$T_{\mathrm{g}, \text { calculated }}\left({ }^{\circ} \mathrm{C}\right)$} & \multirow{2}{*}{$\begin{array}{c}T_{\mathrm{g}, \exp } \\
\left({ }^{\circ} \mathrm{C}\right)\end{array}$} & \multirow{2}{*}{$\begin{array}{c}T_{d, 10 \%} \\
\left({ }^{\circ} \mathrm{C}\right)\end{array}$} \\
\hline & calculated $^{\mathbf{a}}$ & measured & calculated $^{\mathrm{a}}$ & measured & & & Ref 78 & Ref 79 & Ref 80 & & \\
\hline P1 & 45.63 & 43.86 & 5.22 & 4.98 & 14,800 & 2.4 & 53 & 53 & 53 & 52 & 338 \\
\hline P2 & 49.50 & 48.78 & 5.81 & 6.74 & 42,200 & 2.6 & 66 & 66 & 66 & 43 & 331 \\
\hline P3 & 48.28 & 47.86 & 5.30 & 7.34 & 19,600 & 2.1 & 104 & 36 & 46 & 55 & 327 \\
\hline P4 & 32.31 & 32.84 & 3.16 & 5.44 & 20,600 & 2.4 & 13 & 13 & 13 & 26 & 203 \\
\hline P5 & 32.76 & 35.66 & 2.75 & 4.19 & 7,800 & 1.8 & 61 & -14 & -3 & -9 & 217 \\
\hline P6 & 32.61 & 34.26 & 2.89 & 3.33 & 12,600 & 2.7 & 43 & -6 & 2 & 3 & - \\
\hline P7 & 44.36 & 44.57 & 5.59 & 6.46 & 23,800 & 4.4 & -8 & -8 & -8 & -8 & 313 \\
\hline P8 & 38.22 & 38.24 & 4.27 & 5.44 & 25,500 & 5.4 & 8 & 8 & 8 & 14 & 303 \\
\hline P9 & 43.38 & 42.90 & 4.95 & 5.24 & 3,300 & 1.9 & 30 & -27 & -18 & -20 & 291 \\
\hline P10 & 37.92 & 38.57 & 3.75 & 4.68 & 5,300 & 3.6 & 52 & -16 & -6 & 6 & 288 \\
\hline P11 & 34.87 & 34.80 & 3.65 & 4.80 & 25,400 & 3.7 & 11 & 11 & 11 & 23 & - \\
\hline P12 & 37.71 & 37.67 & 4.25 & 7.76 & 18,600 & 5.9 & 3 & 3 & 3 & 11 & - \\
\hline
\end{tabular}

Ref 80: Bonardelli, P.; Moggi, G.; Turturro, A. Polymer 1986, 17, 905-909.

Ref 81: Gelin, M.-P.; Ameduri, B. J. Fluorine Chem. 2005, 126, 577-585.

Ref 82: Rodriguez, F. Principles of polymer systems, 2nd Ed., 1981.

${ }^{\mathrm{a}}$ : amount calculated from the polymer compositions assessed by ${ }^{1} \mathrm{H}$ and ${ }^{19} \mathrm{~F}$ NMR.

As shown in Table 2, experimental weight percentages of carbon and hydrogen, assessed by elemental analysis, contained in co- and ter-polymers were similar to the theoretical values expected in the case of an alternating structure between the fluoroolefins and vinyl ethers. For example, the difference between 
experimental and theoretical carbon content was less than $1 \%$. However, a higher discrepancy appears in the case of hydrogen, probably because of its low content in the copolymer. The proportions of CTFE and HFP in the terpolymers were found to be identical to those of the feed compositions. This quasiquantitative incorporation of these two monomers can be explained by taking into account their nearly identical polarities $\left(e_{\mathrm{CTFE}}=1.56^{64,65} ; e_{\mathrm{HFP}}=1.50^{66}\right)$, but can appear as surprising when considering the lower reactivity of HFP compared to CTFE. The steric hindrance generated by the $\mathrm{CF}_{3}$, and its smaller inductive effect compared to that of chlorine, may be responsible of this behavior. This terpolymerization is an example of Termonomer Induced Copolymerization (TIC), ${ }^{67}$ which associates monomers that do not copolymerize (CTFE and HFP), and a termonomer (VE) that exhibits a good reactivity with the others. Hence, the reactions of polymerization between CTFE, HFP, and CHVE were monitored by NMR spectroscopy to understand how both these fluorooolefins terpolymerized with vinyl ethers. The reaction was carried out in similar conditions as for the poly[(CTFE- alt-CHVE)-co-(HFPalt-CHVE)] terpolymer (P3), but by substituting the water by 1,1,1,3,3-pentafluorobutane. Samples were taken off the reaction media at regular time intervals to monitor the evolution of the incorporation of HFP in the polymer by NMR spectroscopy versus the conversion in CHVE (considering that the resulting polymers is alternated, the conversion of CHVE can be used as a reference).

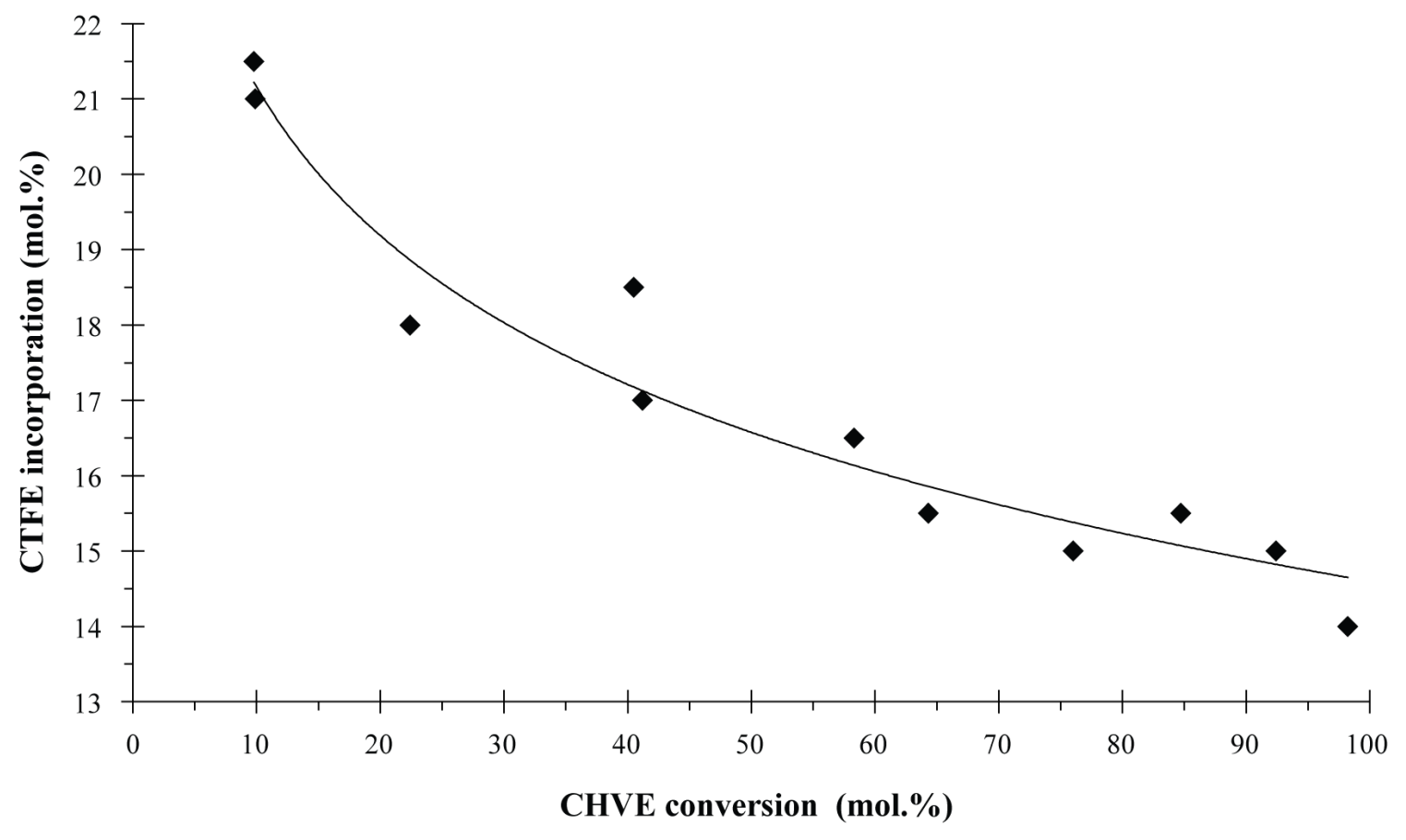


Figure 1. Evolution of the incorporation ratio of chlorotrifluoroethylene (CTFE) versus the cyclohexylvinyl ether (CHVE) conversion during the terpolymerization between CTFE (10 mol.\%), hexafluoropropylene (HFP) (40 mol.\%), and CHVE (50 mol.\%), at $67{ }^{\circ} \mathrm{C}$, initiated by tert-butylperoxypivalate (TBPPi) in $\mathrm{C}_{4} \mathrm{~F}_{5} \mathrm{H}_{5}$.

The results displayed in Figure 1 show that the first terpolymers were relatively rich in CTFE (22 mol.\% for a CHVE conversion below $10 \%$ ) while the initial percentage of this monomer was 10 mol.\% (with $40 \mathrm{~mol} \%$ of HFP, and 50 mol.\% of CHVE). Thus, although at the end of the polymerization, the amount of CTFE was ca. $15 \mathrm{~mol} \%$ (a value close to the initial value) this evolution of the proportion of CTFE, and hence of HFP, in the terpolymer was the consequence of the lower reactivity of HFP towards CTFE. Furthermore, HFP does not homopolymerize, ${ }^{6}$ and thus, copolymers with such a high content of HFP (> 30 mol.\%) are rare. In addition, the copolymers containing HFP have lower molecular weights than those of poly(CTFE-alt-VE) copolymers, though both types of copolymers were obtained with similar yields (> 80 wt.\%). In fact, the molecular weights of HFP-containing copolymers were high enough when HFP was the only fluoroolefin, while when HFP was copolymerized with CTFE, the molecular weights decreased. As expected, the polymerizations carried out in aqueous media ${ }^{22,24}$ led to much higher molecular weights than the polymerizations in solution ${ }^{68,69}$. However, the hypothesis of the transfer to the solvent during the terpolymerization to explain the lower molecular weight could not be considered since $1,1,1,3,3$-pentafluorobutane has a negligible transfer constant. ${ }^{70,71}$ 


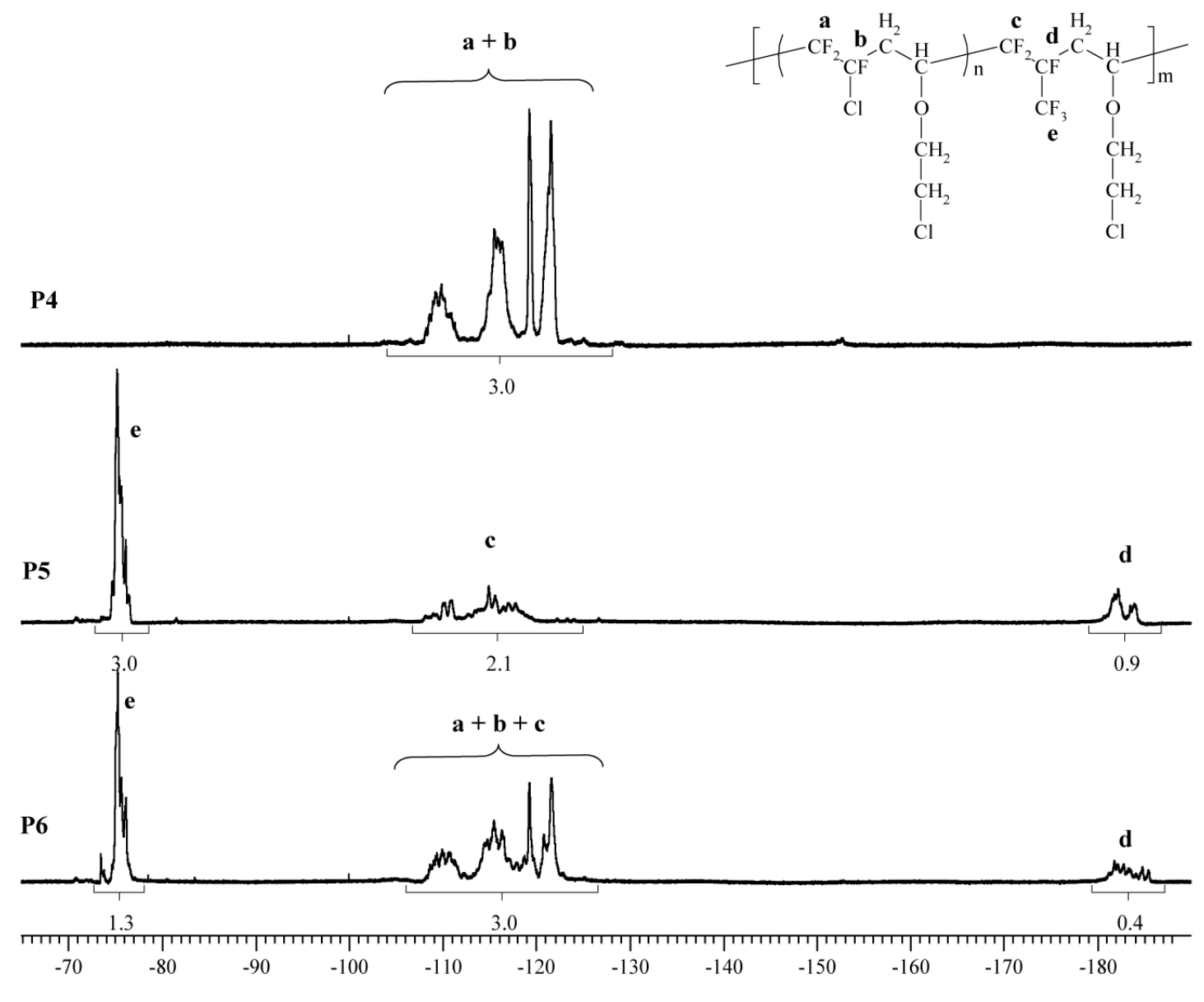

Chemical Shift (ppm)

Figure 2. ${ }^{19}$ F NMR spectra of poly(CTFE-alt-CEVE) (P4), poly(HFP-alt-CEVE) (P5), and poly[(CTFE alt-CEVE)-co-(HFP-alt-CEVE)] (P6) copolymers in $\mathrm{CDCl}_{3}$. (CEVE and HFP stand for 2-chloroethylvinyl ether and hexafluoropropylene, respectively)

Figure 2 represents the ${ }^{19} \mathrm{~F}$ NMR spectra of the different poly(CTFE-alt-CEVE) and poly(HFP-altCEVE) copolymers, and of poly[(CTFE alt-CEVE)-co-(HFP-alt-CEVE)] terpolymers. Though the $\mathrm{CF}_{3^{-}}$ and -CF- signals were well separated (-75 ppm vs. $-183 \mathrm{ppm})$, it was difficult to separate the integrals of the signals of the $-\mathrm{CF}_{2}$ ( (ranging from -109 to $\left.-123 \mathrm{ppm}\right)^{72}$ assigned to both HFP and CTFE.

Similarly, the ${ }^{1} \mathrm{H}$ NMR spectrum (Supporting Information Figure A) allowed to assess the proportion of vinyl ethers in the polymer. ${ }^{63}$ This figure shows the methylene and methyne protons of the main chain centered at 4.6 and $2.8 \mathrm{ppm}$, respectively. The other peaks were assigned to the alkyl pendant chain of the vinyl ether (alkyl groups between 0.8 to $2.2 \mathrm{ppm}$, and $\mathrm{CH}_{2} \mathrm{X}$ (where $\mathrm{X}=\mathrm{O}$ or halogen) between 3.5 to 
$4.2 \mathrm{ppm})$. The incorporation of CEVE and CHVE units in the polymers fits with the feed composition (see Table 1 and 2). This good agreement is not surprising considering the relatively close polarity of those vinyl ethers $\left(e_{\mathrm{CEVE}}=-1.80 ; e_{\mathrm{CHVE}}=-1.55\right) .{ }^{65}$ The molar masses of these copolymers assessed by SEC are listed in Table 2 and they vary from 3,300 to 42,200 g. $\mathrm{mol}^{-1}$, similar as those of Lumiflon ${ }^{\circledR}$ or Zeffle ${ }^{\circledR}{ }^{23}$ Although they could be considered as low molecular weights, they are sufficient for binder application that does not require outstanding mechanical properties.

From various vinyl ethers, different copolymers were produced, endowed with glass transition temperatures $\left(T_{\mathrm{g}}\right)$ ranging from -20 to $+55^{\circ} \mathrm{C}$ (Table 2). For example, the copolymers containing BVE, which is known to lower the $T_{\mathrm{g}}$, present the lowest $T_{\mathrm{g}}(\mathrm{P} 7, \mathrm{P} 9$, and P12), although P5 also exhibits a low $T_{\mathrm{g}}\left(-9^{\circ} \mathrm{C}\right)$ due to the absence of CTFE. The synthesis of polymers with different $T_{\mathrm{g}}$ is of interest to obtain, after chemical modification, polymers with different film forming properties, which is an essential aspect for the determination of the electrochemical properties. Indeed, the membrane must be neither too soft to prevent flowing in water, nor to be too brittle for its suitable processing such as casting and handling during the characterization. Several equations can be used to assess the $T_{\mathrm{g}}$ of a copolymer as a function of its composition ${ }^{73-77}$. Theoretical values of the glass transition temperature of the copolymers were calculated according to the Fox equation ${ }^{74}$ that was developed for copolymers. This equation links the reverse of the $\mathrm{T}_{\mathrm{g}}$ of a copolymer to the weight fraction, $\mathrm{w}_{\mathrm{i}}$, and the glass transition temperature, $\mathrm{T}_{\mathrm{gi}}$ (in Kelvin) of the corresponding homopolymer considering each monomer $\mathrm{i}$ as indicated in equation 6:

$$
\frac{1}{T_{\mathrm{g}}}=\sum_{\mathrm{i}} \frac{\mathrm{W}_{\mathrm{i}}}{T_{\mathrm{gi}}}
$$

The theoretical $T_{\mathrm{g}}$ values of each homopolymer based on CTFE, CHVE, EVE, and BVE were +52 , $+81,-43$, and $-55^{\circ} \mathrm{C}$, respectively. The $T_{\mathrm{g}}$ of poly(CEVE), determined by Schappacher and Deffieux ${ }^{78,79}$ was used $\left(\mathrm{T}_{\mathrm{g}}(\right.$ poly $\left.(\mathrm{CEVE}))=-21^{\circ} \mathrm{C}\right)$. As HFP does not homopolymerize, it is not possible to use an experimental value though the literature reports several calculated values ${ }^{80-82}$, and we have considered those determined by Bonardelli et al. $^{80}\left(\mathrm{~T}_{\mathrm{g}}(\right.$ poly $\left.(\mathrm{HFP}))=+160{ }^{\circ} \mathrm{C}\right)$, Gelin and Ameduri ${ }^{81}$ 
$\left(\mathrm{T}_{\mathrm{g}}(\right.$ poly $\left.(\mathrm{HFP}))=-9{ }^{\circ} \mathrm{C}\right)$, and Rodriguez et al. ${ }^{82}\left(\mathrm{~T}_{\mathrm{g}}(\right.$ poly $\left.(\mathrm{HFP}))=+11{ }^{\circ} \mathrm{C}\right)$. The experimental values of the glass transition temperatures are listed in Table 2, and were found generally to be nearly identical (P1, P5, P6, P7, P8, P9) or quite close (P2, P3, P4, P10, P11, P12) to the calculated ones. It was found that calculations based on the value determined by Rodriguez et al ${ }^{82}$ for poly(HFP) gave the best agreement. If the copolymerizations carried out by Gelin and Ameduri ${ }^{81}$ were achieved in similar conditions as those of the present copolymerizations, those of Bonardelli et al. ${ }^{80}$ were carried out in emulsion. As the glass transition temperature is related to the morphology, and hence to the microstructure (conformation, molecular weight...) which depends on the polymerization method, some variations in the $T_{g}$ values can be expected (from -9 to $+160{ }^{\circ} \mathrm{C}$ ).

Finally, the existence of only one $T_{g}$ for each terpolymer is an important observation proving that the product is indeed a terpolymer and not a mixture of two copolymers (poly[CTFE-alt-VE] and poly[HFPalt-VE]. Neither NMR spectroscopy, nor elemental analysis, nor SEC chromatography (especially because the PDI of the polymers is generally large) could underline this point.

Chemical Modification of the copolymers. Three steps were required to modify the above copolymers starting from replacing the chlorine atom by an iodine one, then by trimethylamine. Finally, the iodine counter-ion was exchanged with hydroxide ions (Scheme 2).

Scheme 2: Modification of the poly(CTFE-alt-VE) alternating copolymers by iodination, cationization by trimethylamine (TMA), and then counter-ion exchange by sodium hydroxide. 
Iodination of the copolymers.

When the direct amination of the chlorine atoms by trimethyl amine was carried out, no substitution was observed. Thus, since the dissociation energy of $\mathrm{CH}_{2}-\mathrm{Cl}$ bond is higher than that of $\mathrm{CH}_{2}-\mathrm{I}$, an intermediate step of iodination of CEVE-based copolymers and terpolymers was performed. This reaction has been described in the literature on the same monomer (2-chloroethylvinyl ether) ${ }^{83,84}$. This intermediate step enables the further cationization since the chlorine atom is not reactive enough to be substituted by a tertiary amine. The low solubility in acetone of the sodium chloride formed during the substitution compared to those of the sodium iodide enabled to reach high conversions.

Hence, the iodination was initially tested and monitored by ${ }^{1} \mathrm{H}$ NMR on CEVE monomer, to determine and to apply the optimal conditions for the modification of the copolymers containing CEVE (Supporting Information, Figure B). The evaluation of the conversion, $\alpha_{\mathrm{IEVE}}$, was noted from the high field shift of the triplet from 3.82 to 3.45 ppm assigned to $\mathrm{CH}_{2} \mathrm{Cl}$ into $\mathrm{CH}_{2} \mathrm{I}$ (Figure 4), as follows:

$$
\alpha_{I E V E}=\frac{\int_{3.45} \mathrm{CH}_{2} \mathrm{I}}{\int_{3.45} \mathrm{CH}_{2} \mathrm{I}+\int_{3.82} \mathrm{CH}_{2} \mathrm{Cl}}
$$

where $\int \mathrm{CH}_{2} \mathrm{X}$ represents the integral of the signal assigned to the $\mathrm{CH}_{2} \mathrm{X}$ group.

Figure 3 represents the conversion of CEVE into 2-iodoethylvinyl ether (IEVE), $\alpha_{\mathrm{CEVE}}$, versus time according to the concentration of monomer obtained with 3 equivalents of $\mathrm{NaI}$, in acetone, at $65^{\circ} \mathrm{C}$. 


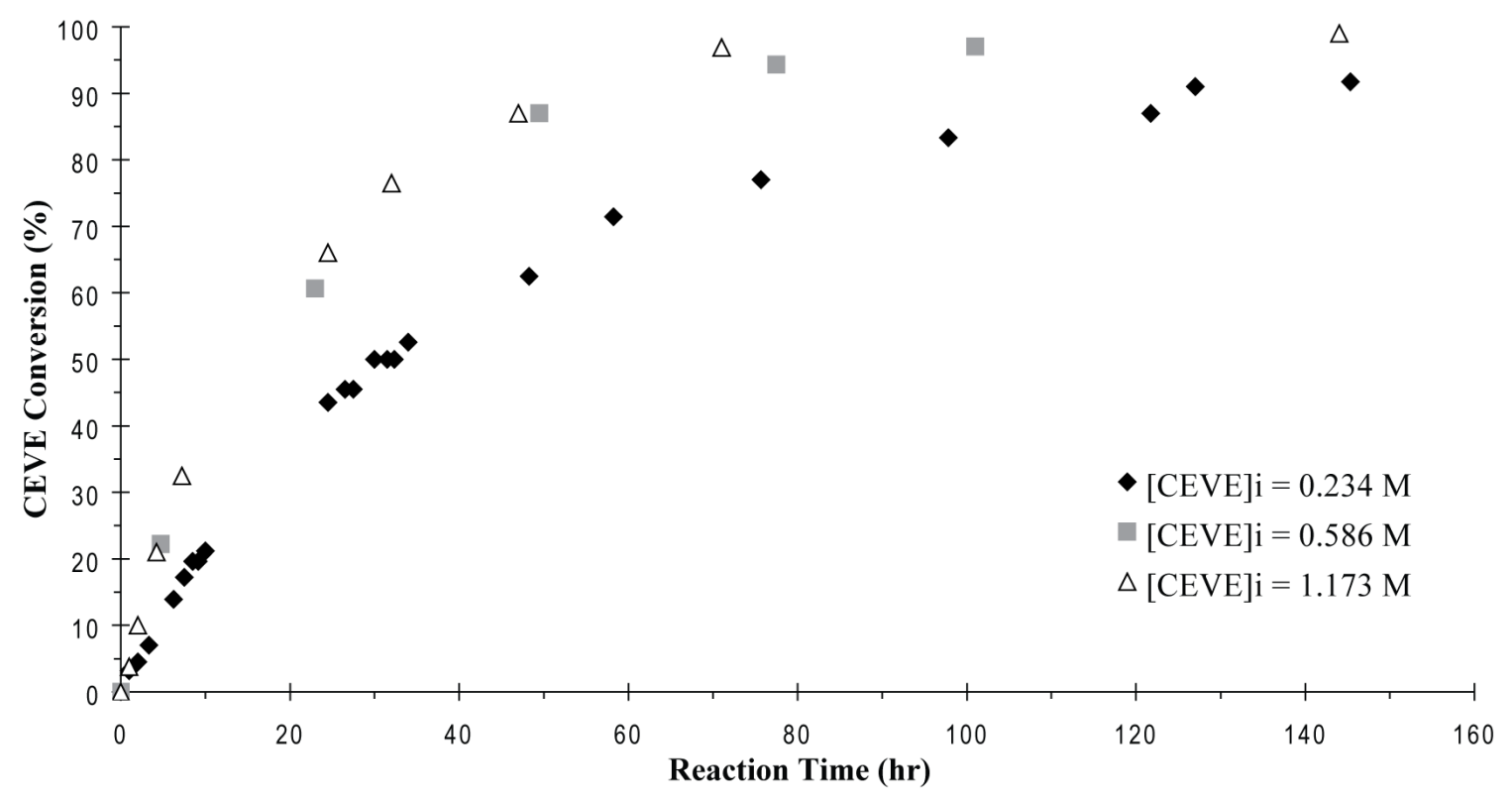

Figure 3. Conversion of 2-chloroethylvinyl ether (CEVE) monomer into 2-iodoethylvinyl ether (IEVE) versus time for different initial CEVE concentrations at $65^{\circ} \mathrm{C}$, in the presence of a 3 foldexcess of NaI with respect to CEVE.

A CEVE concentration of 0.234 mol. $\mathrm{L}^{-1}$ allowed a quasi complete conversion after 7 days. As expected, the higher the concentration, the faster the reaction. However, beyond a concentration of 0.6 mol. $L^{-1}$, the rate of the reaction did not increase further. Such an exchange reaction is called a Finkelstein reaction. ${ }^{85}$ This $\mathrm{S}_{\mathrm{N}} 2$ nucleophilic substitution occurs with a single step mechanism, and when the solution is saturated in iodide salt, its concentration can be considered as constant, and the kinetics of that reaction is a pseudo first order. Plotting $\ln \left([\mathrm{CEVE}] /[\mathrm{CEVE}]_{0}\right)$ versus the reaction time led to a straight line, the slope of which is the rate constant $\mathrm{k}=1.0 .10^{-5} \mathrm{~s}^{-1}$ at $65{ }^{\circ} \mathrm{C}$ (supporting information Figure C). Hence, that reaction of iodination was transposed onto copolymers. They were analyzed by ${ }^{1} \mathrm{H}$ NMR spectroscopy (Figure 4). Spectra obtained showed a high field shift of the signal corresponding to the protons adjacent to the halogen atom from $3.5 \mathrm{ppm}$ when linked to a chlorine atom, to $3.1 \mathrm{ppm}$ when located close to an iodine atom. From the comparison of the ${ }^{1} \mathrm{H}$ NMR spectra of P5 and $\mathrm{P} 5 \mathrm{i}$ products, a small remaining signal assigned to $-\mathrm{CH}_{2} \mathrm{Cl}$ groups $(3.5 \mathrm{ppm})$ could be observed. 

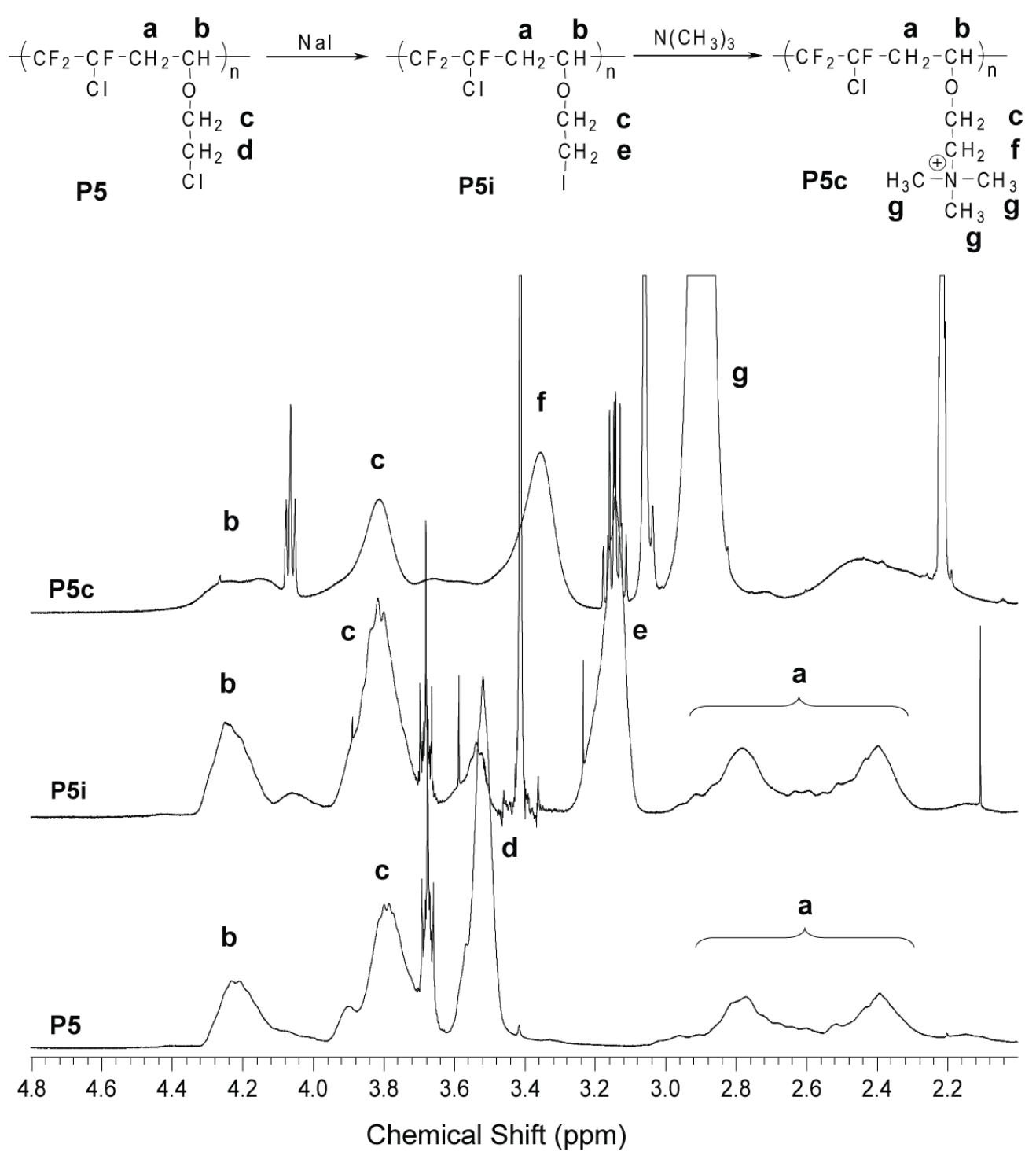

Figure 4. ${ }^{1} \mathrm{H}$ NMR spectra of the poly(HFP-alt-CEVE) copolymer (P5), iodinated (P5i), and cationized (P5c), in $\mathrm{CDCl}_{3}$ for the first two and in DMSO d6 for the third one.

The yields, reported in Table 3, show the difficulty to modify the copolymers completely, and the problems noted when adapting a reaction from a model compound to a polymer. These lower conversion values may arise from the lower solubility of the copolymer in acetone compared to the monomer. The lower access of the reagent to the $-\mathrm{CH}_{2} \mathrm{Cl}$ sites due to the entanglement of the polymer coils may also be responsible. Different reaction times were also attempted on the poly[(CTFE-alt-CEVE)-co-( CTFE-altCHVE)] terpolymer (P1) showing an increase of the yield from 2 days (P1i1) to 7 days (P1i2) (Table 3).

Table 3. Substitution of the chlorine atoms by iodine atoms from CEVE in the different poly(CTFE-alt-VE) copolymers after various reaction times. 


\begin{tabular}{cccccccc}
\hline Sample & P1i1 & P1i2 & P4i & P5i & P6i & P11i & P12i \\
\hline $\mathbf{t}_{\mathbf{R}}$ (days) & 2 & 7 & 7 & 7 & 7 & 7 & 7 \\
yield(\%) & 55 & 85 & 64 & 77 & 87 & 81 & 90 \\
\hline
\end{tabular}

where the "i" suffix in the sample name stands for iodinated copolymer

Iodination carried out at reflux of acetone in the presence of 3 equivalents of NaI.

Yield assessed by ${ }^{1} \mathrm{H}$ NMR

\section{Amination of the copolymers.}

The ammonium groups were introduced via a substitution of the iodoalkyl groups of the copolymers by trimethylamine (TMA). This type of nucleophilic substitutions has successfully been achieved on copolymers bearing poly(vinylbenzylchloride) side-groups at $40{ }^{\circ} \mathrm{C}$, and the reaction time between TMA and the iodine atom in the copolymer did not exceed $48 \mathrm{hrs} .{ }^{86-91}$ Our reactions were carried out under that procedure. In some cases, a change of the solubility was observed after $24 \mathrm{hrs,} \mathrm{corresponding} \mathrm{to} \mathrm{a}$ deep change in the chemical nature of the polymer resulting in a modification of its behavior in solution. This drift in solubility can be considered as an evidence of the grafted ammonium groups. The evolution of the chemical structure of the copolymer was monitored by ${ }^{1} \mathrm{H}$ NMR spectroscopy, and is shown in Figure 4. Originally centered at $3.1 \mathrm{ppm}$ when linked to an iodine atom, the signal of the terminal methylene shifted to $3.3 \mathrm{ppm}$ when adjacent to an ammonium group. Other signals, located between 2.3 and $2.9 \mathrm{ppm}$, at $3.8 \mathrm{ppm}$, and at $4.2 \mathrm{ppm}$ corresponding to $-\mathrm{CTFE}-\underline{\mathrm{C}}_{2}-\mathrm{CH}(\mathrm{OR})-\mathrm{CTFE}-,-\mathrm{O}-\mathrm{C}_{2}-\mathrm{CH}_{2}$, and -CTFE- $\mathrm{CH}_{2}-\mathrm{C} \underline{\mathrm{H}}(\mathrm{OR})-\mathrm{CTFE}-$, respectively, remained unchanged.

In addition, the ${ }^{1} \mathrm{H}$ NMR spectra showed that the substitution by TMA was not associated with an elimination reaction (dehydroiodination), which could have occurred due to the basicity of the amine, and to the high reactivity of the iodine. Indeed, a dehydroiodination side-reaction would have led to the formation of a vinyl group, which protons would have appeared in the 5-7 ppm range in the ${ }^{1} \mathrm{H}$ NMR spectrum.

Stability of Poly(CTFE-alt-VE) copolymers in basic media. Poly(CTFE-alt-VE) alternating copolymers are composed of CTFE/VE diads which contain a succession of methylene and chlorofluoromethylene units. These diads may undergo a reaction of dehydrofluorination or 
dehydrochlorination under basic conditions, and it was necessary to study their behavior in highly basic media. Although the stability in such conditions of analogous polymers such as ECTFE has been demonstrated, ${ }^{35,37,39}$ the stability of poly(CTFE-alt-VE) copolymers, satisfactory in acidic media ${ }^{92}$, remains unclear in basic media, and was worth investigating. A poly(CTFE-alt-CHVE) alternating copolymer was synthesized by radical polymerization and obtained in $74 \%$ yield (P2, Table 1$)$. The molecular weight, measured by SEC, led to $\mathrm{M}_{\mathrm{n}}=12,100 \mathrm{~g} \mathrm{~mol}^{-1}$ with a polydispersity index of 1.9 . To evaluate its stability in basic media, it was dipped into various basic solutions at different temperatures. The conditions are listed in Table 4. NMR and SEC analyses were performed to investigate any possible degradation/ageing and no changes were observed (see supporting information). Also no change of color was observed whatever the conditions.

Table 4. Chemical stability of poly(CTFE-alt-CHVE) alternating copolymers in basic media.

\begin{tabular}{ccccc}
\hline Sample & Basic Media* & $\begin{array}{c}\text { T } \\
\left({ }^{\circ} \mathbf{C}\right)\end{array}$ & $\begin{array}{c}\text { t } \\
(\text { days })\end{array}$ & Solvent \\
\hline S1 & $\mathrm{NaOH}\left(2.5 \mathrm{~mol} . \mathrm{L}^{-1}\right)$ & 50 & 7.0 & Water $(100 \mathrm{~mL})$ \\
S2 & $\mathrm{NaOH}\left(1.25 \mathrm{~mol} . \mathrm{L}^{-1}\right)$ & 50 & 7.0 & Water + DMF $(1: 1 \mathrm{vol}, 100 \mathrm{~mL})$ \\
S3 & $\mathrm{H}_{2} \mathrm{~N}-\left(\mathrm{CH}_{2}\right)_{3}-\mathrm{N}\left(\mathrm{CH}_{3}\right)_{2}(2 \mathrm{eq})+\mathrm{TEA}(2 \mathrm{eq})$ & 90 & 2.2 & Toluene $(100 \mathrm{~mL})$ \\
S4 & $\mathrm{TEA}(3 \mathrm{eq})$ & 90 & 7.0 & DMF $(40 \mathrm{~mL})$ \\
S5 & TMA (3 eq) & 25 & 7.0 & Toluene $(40 \mathrm{~mL})$ \\
S6 & TEA (3 eq) & 90 & 3.2 & Acetonitrile $(100 \mathrm{~mL})$ \\
S7 & $\mathrm{HO}-\left(\mathrm{CH}_{2}\right)_{2}-\mathrm{SH}(2 \mathrm{eq})+\mathrm{TEA}(2 \mathrm{eq})$ & 90 & 7.0 & DMF $(40 \mathrm{~mL})$ \\
\hline
\end{tabular}

where the "S" prefix in the sample name stands for Stability

TEA = triethylamine

$\mathrm{TMA}=$ trimethylamine

$\mathrm{T}=$ temperature

$\mathrm{t}=$ time

* The amount of amines is noted as equivalent to the (CTFE-CHVE) units.

The ${ }^{1} \mathrm{H}$ NMR spectrum (Figure 5) clearly shows the methylene protons of the cyclohexyl groups in the region ranging from 0.9 to $2.3 \mathrm{ppm}$, while the methylene protons of the main chain are located between 2.4 and $3.5 \mathrm{ppm}$. The methyne are also clearly identified at $4.8 \mathrm{ppm}$ (for the one from the main chain) and at $3.6 \mathrm{ppm}$ for the cyclohexyl one. This difference of chemical shifts is a further evidence of the alternation in which the difluoromethylene adjacent to the methyne in the backbone induces a low field shift. As evidenced from this ${ }^{1} \mathrm{H}$ NMR spectrum, no apparent degradation of the cyclohexyl group was observed since none of the corresponding signals have been affected. Furthermore, no modification 
of the backbone was observed either, especially at the junctions between methylene and fluoromethylene groups where a dehydrofluorination reaction could be expected (the formation of $\mathrm{a}-\mathrm{CH}=\mathrm{CF}-$ double bond would induce the presence of the signal beyond $6.0 \mathrm{ppm}) .{ }^{93-98}$

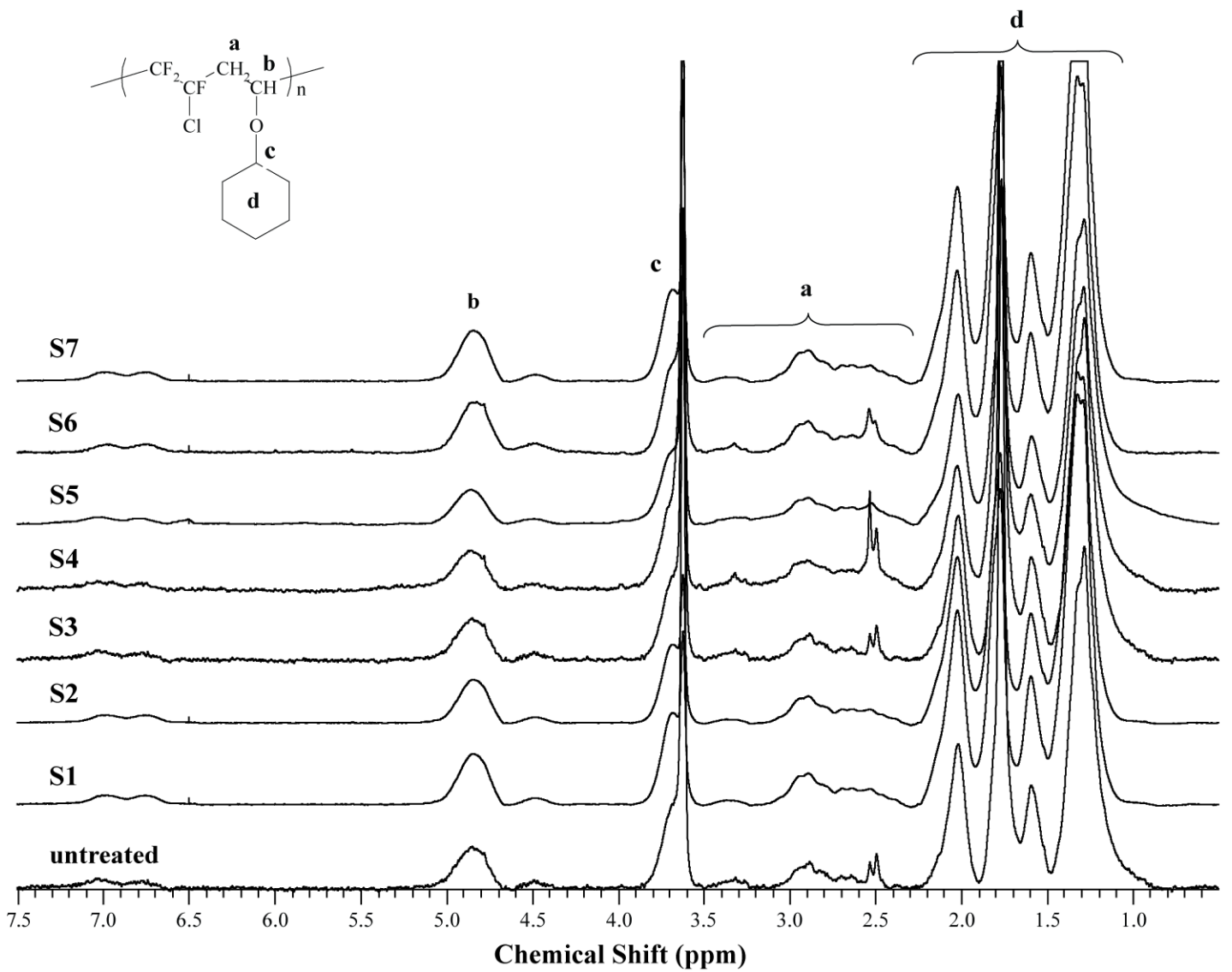

Figure 5. ${ }^{1} \mathrm{H}$ NMR spectra of the poly(CTFE-alt-CHVE) copolymer (untreated, lower spectrum) and exposed to various basic solutions (S1-S7 in Table 4): S1: NaOH (2.5 mol.L $\mathrm{L}^{-1}$ ) days; S2: NaOH (1.25 mol.L $\left.{ }^{-1}\right) 7$ days; S3: $\mathrm{H}_{2} \mathrm{~N}-\left(\mathrm{CH}_{2}\right)_{3}-\mathrm{N}\left(\mathrm{CH}_{3}\right)_{2}(2 \mathrm{eq})+\mathrm{N}\left(\mathrm{CH}_{2} \mathrm{CH}_{3}\right)_{3}$ (2 eq) 2.2 days; S4: $\mathrm{N}\left(\mathrm{CH}_{2} \mathrm{CH}_{3}\right)_{3}(3 \mathrm{eq}) 7$ days; S5: $\mathrm{N}\left(\mathrm{CH}_{3}\right)_{3}$ (3 eq) 7 days; S6: $\mathrm{N}\left(\mathrm{CH}_{2} \mathrm{CH}_{3}\right)_{3}$ (3 eq) 3.2 days; S7: HO$\left(\mathrm{CH}_{2}\right)_{2}-\mathrm{SH}(2 \mathrm{eq})+\mathrm{N}\left(\mathrm{CH}_{2} \mathrm{CH}_{3}\right)_{3}(2$ eq $) 7$ days.

The ${ }^{19}$ F NMR spectra (Supporting Information, Figure D) also confirm the stability of these copolymers since no evolution of the signals in the spectra has been observed (if fluorovinyl groups ($\mathrm{CH}=\mathrm{CF}-$ ) would have been formed, a new signal should be present at $-118 \mathrm{ppm})^{98,99}$.

The SEC analyses of the different copolymers (untreated, S1-S7) (Supporting Information, Figure E) show in some cases a slight increase in molecular weight (13,200 vs. 12,120 g/mol) accompanied by a slight decrease in the polydispersity index (1.70 vs. 1.92). This phenomenon appeared for samples treated by amines or thiol solutions, where the reaction was carried out in an organic solvent, and a 
precipitation was necessary to isolate the product, which tends to eliminate the lowest molecular weight fraction. For sample treated by sodium hydroxide aqueous solution, a simple filtration was enough to recover all the product.

Under basic conditions, poly(CTFE-alt-CHVE) copolymers were clearly more stable than poly(VDF) polymers $^{93-98}$ which undergo a dehydrofluorination. This arises from the presence of two $\mathrm{CF}_{2}$ groups, adjacent to the $\mathrm{CH}_{2}$ groups in poly(VDF) which have an electron-withdrawing effect making the protons in methylene groups more acidic, and consequently more sensitive to bases.

Electrochemical and Thermal Properties. Although these present poly[(CTFE alt-VE)-co-(HFP-altVE)] terpolymers did not require good mechanical properties to be cast as electrode binders, the characterization of the properties such as ionic exchange capacity (IEC), swelling ratio or ionic conductivity implied the preparation of self-supporting membranes to assess such analyses.

Electrochemical properties. Table 5 lists the obtained values for all electrochemical properties (IEC, swelling and conductivity) of all the poly(CTFE-alt-CEVE) copolymers and poly[(CTFE alt-CEVE)-co(CTFE-alt-VE)] terpolymers as well as their composition.

Table 5. Membrane related properties of the different cationized poly[(CTFE alt-VE)-co-(HFPalt-VE)] terpolymers and a recall of their composition.

\begin{tabular}{|c|c|c|c|c|c|c|c|c|}
\hline \multirow[b]{2}{*}{ Sample } & \multicolumn{4}{|c|}{ Copolymer Composition (\%) } & \multirow{2}{*}{$\begin{array}{c}\text { IEC }_{\text {th }}^{\text {b }} \\
\left(\mathrm{meq}^{-1} \mathrm{~g}^{-1}\right)\end{array}$} & \multirow{2}{*}{$\begin{array}{c}\text { IEC }_{\text {exp }} \\
\left(\mathrm{meq}^{-1} \mathrm{~g}^{-1}\right)\end{array}$} & \multirow{2}{*}{$\begin{array}{c}\text { Water } \\
\text { Uptake } \\
(\%)^{\mathbf{a}}\end{array}$} & \multirow{2}{*}{$\begin{array}{l}\text { Conductivity } \\
\left(\mathrm{mS}^{\left.-\mathrm{cm}^{-1}\right)}\right.\end{array}$} \\
\hline & CTFE & HFP & CEVE & $\mathbf{V E}$ & & & & \\
\hline P1c1 & 50 & - & 12 & CHVE (38) & 0.52 & 0.50 & 19 & 0.13 \\
\hline P1c2 & 50 & - & 12 & CHVE (38) & 0.81 & 0.72 & 25 & - \\
\hline P4c & 50 & - & 50 & - & 2.42 & 0.66 & 13 & - \\
\hline P5c & 0 & 50 & 50 & - & 3.36 & \multicolumn{3}{|c|}{ Water-soluble } \\
\hline P6 $c^{c}$ & 31.5 & 18.5 & 50 & - & 3.63 & \multicolumn{3}{|c|}{ Water-soluble } \\
\hline P11c & 50 & 0 & 26 & EVE (24) & 1.93 & \multicolumn{3}{|c|}{ Water-soluble } \\
\hline P12c & 50 & 0 & 27 & BVE (23) & 2.11 & \multicolumn{3}{|c|}{ Water-soluble } \\
\hline
\end{tabular}

where the "c" suffix in the sample name stands for cationized copolymer

Standard deviation: conductivity : $12 \%$; water content : $5 \%$; IEC : $12.5 \%$.

Thickness $\mathrm{P} 1 \mathrm{cl}=125 \mu \mathrm{m}$

Solubility: $1 \mathrm{~g}$ of polymer for $2 \mathrm{~g}$ of dimethylsulfoxide

${ }^{\mathrm{a}}: \mathrm{m}_{\mathrm{h}}-\mathrm{m}_{\mathrm{s}} / \mathrm{m}_{\mathrm{S}}=$ mass of product relative to the mass of solvent.

$\mathrm{b}$ : calculated regarding to the amount of CEVE, in the condition where all $\mathrm{Cl}$ have been substituted by ammonium groups : 
$\mathrm{IEC}_{\text {th }}=\frac{\% \mathrm{CEVE} \times 1000}{\% \mathrm{CEVE} \times \mathrm{M}_{\mathrm{TMAEVE}}+\% \mathrm{VE} \times \mathrm{M}_{\mathrm{VE}}+\% \mathrm{CF}_{2} \mathrm{CFX} \times \mathrm{M}_{\mathrm{CF}_{2} \mathrm{CFX}}} \times \mathrm{T}_{\mathrm{I}}$

where $\% \mathrm{VE}$ et $\% \mathrm{CF}_{2} \mathrm{CFX}$ represent the vinyl ether fractions (CHVE, EVE or BVE) and fluorinated olefins (CTFE and/or HFP) fractions in the copolymer, respectively, and $\mathrm{M}_{\mathrm{TMAEVE}}$ the molar mass of cationized CEVE by TMA, and washed with sodium hydroxide (TMAEVE = trimethylethylvinyl ether ammonium) and $\mathrm{T}_{\mathrm{I}}$ the ratio iodinated of the copolymer

${ }^{c}$ : initial non-precipitated copolymer.

Some cationized copolymers were water-soluble (P5c, P6c, P11c, P12c) and could not be used as electrode binder while others were not water-soluble (P1c1, P1c2, and P4c) and did have the adequate solubility in DMSO to be tested as well. P1c1 and P1c2 probably owed their insolubility in water to their low ratio of hydrophilic ammonium groups compared to hydrophobic cyclohexyl groups. This hypothesis cannot be assumed in the case of P4c, since this copolymer had the highest theoretical IEC (2.42 meq. $\left.\mathrm{g}^{-1}\right)$. In this case, the explanation may arise from the mechanical properties. Since the synthesized copolymers have a similar molecular weights $\left(7,800\right.$ g.mol ${ }^{-1}<M_{\mathrm{n}}<25,400$ g.mol $\left.{ }^{-1}\right)$, the crystallinity and the glass transition temperature varied according to the nature of the incorporated monomers. Also the accessibility to the ammonium sites on the polymer chains can also play a major role. Nevertheless, both P1c2 and P4c got broken during the conductivity test.

The water content of the water insoluble quaternary ammonium-modified polymers varied between 13 and $25 \%$ with IEC values ranging from 0.5 to 0.72 meq. $\mathrm{g}^{-1}$. Regarding the conductivity, the brittleness of P1c2 and P4c prevented from any measurement, and only P1c1 could be assessed $\left(0.13 \mathrm{mS} . \mathrm{cm}^{-1}\right)$. Table 5 shows how difficult it was to find out the suitable compromise to obtain the optimal conductivity, favored by the largest amount of ammonium group and water insolubility. For example, P1c1 copolymer, with the lowest amount of CEVE, and consequently the lowest amount of ammonium groups $\left(\right.$ IEC $_{\text {th }}=0.52$ meq. $\left.\mathrm{g}^{-1}\right)$, was not water-soluble, which allowed to assess its IEC $\left(0.5\right.$ meq.g $\left.{ }^{-1}\right)$ and its conductivity $\left(0.13 \mathrm{mS} . \mathrm{cm}^{-1}\right)$ values. The reverse case happened for P5c, P6c, P11c, and P12c copolymers where the ammonium content is higher, but this resulting water-solubility made them impossible to be used as electrodes binders. 
Thermal Analysis. Figure 6 represents the thermograms obtained by thermogravimetric analysis (TGA) for the P1 and P4 copolymers in its chlorinated or ammoniated forms. Under the conditions used for the TGA $\left(25-550^{\circ} \mathrm{C}\right.$ at $10^{\circ} \mathrm{C} \cdot \mathrm{min}^{-1}$, under air), the poly(CTFE-alt-CHVE) (P2) and poly(CTFE-altEVE) (P8) copolymers had an initial degradation temperature above $300^{\circ} \mathrm{C}$ in good agreement with the literature. $^{57,100}$ The decomposition temperatures at $10 \%$ weight loss (Table 2) show that most unmodified polymers do not decompose up to $300{ }^{\circ} \mathrm{C}$. The comparison of the thermograms (Figure 6) clearly shows the thermal stability loss of the copolymers modified with the ammonium groups. The thermal stability was much affected when the ammonium ratio increased. This degradation is closely linked to the Hoffman type degradation reaction of these ammonium groups. ${ }^{101}$

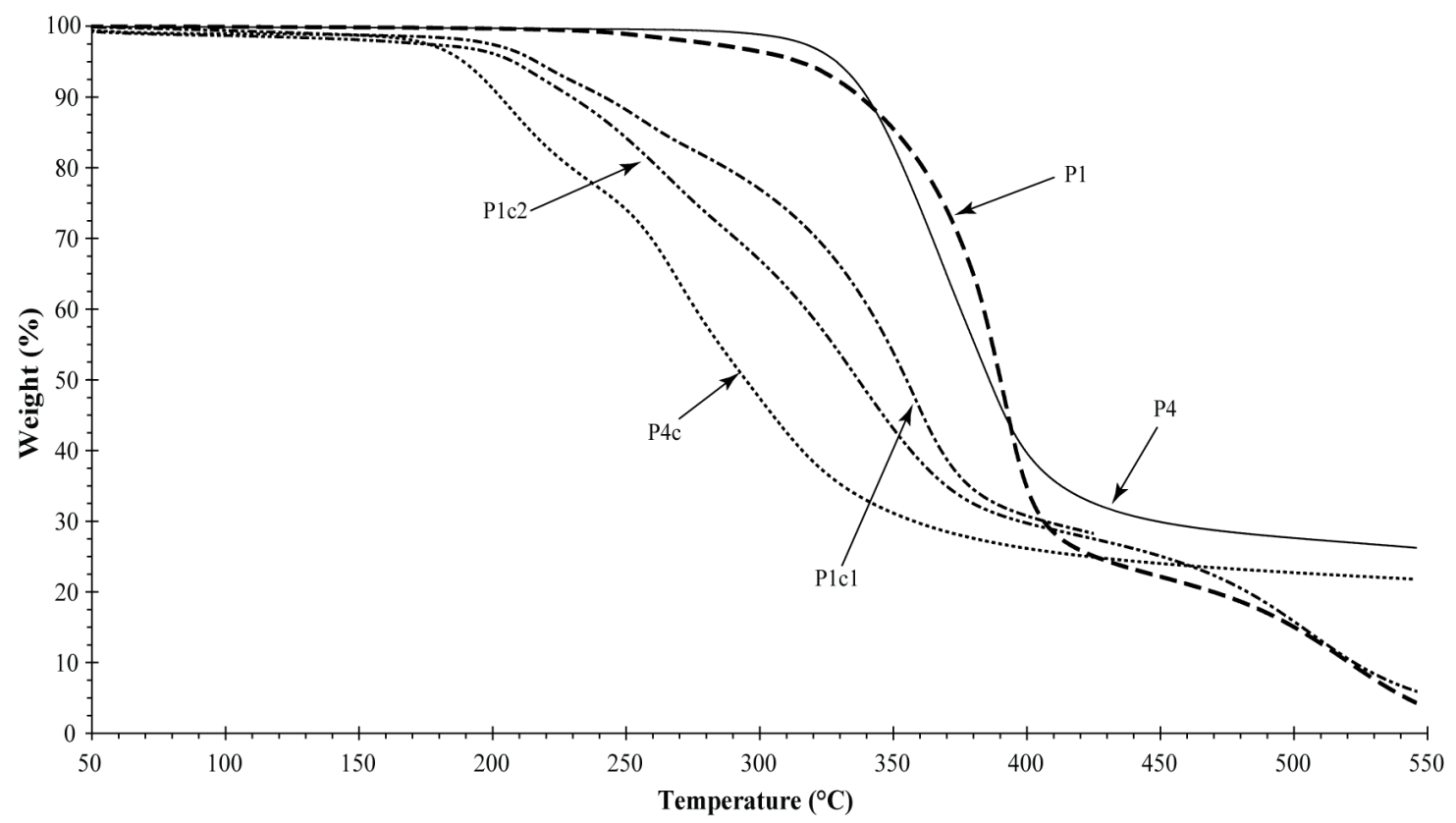

Figure 6. TGA thermograms (under air, at $10{ }^{\circ} \mathrm{C} \cdot \mathrm{min}^{-1}$ ) of the initial (P4) and cationized (P4c) poly(CTFE-alt-CEVE) copolymers, and the original (P1), slightly cationized (P1c1), and highly cationized (P1c2) poly[(CTFE-alt-CHVE)-co-(CTFE-alt-CEVE)] terpolymers.

Although no clear indication on the thermostability could be drawn from the TGA thermograms, it is safe to assume that these copolymers should resist at $50{ }^{\circ} \mathrm{C}$ regarded as the fuel cell operating conditions. In addition, during the preparation of the membranes, the samples were dried at $50{ }^{\circ} \mathrm{C}$ for 24 hrs and no change was observed in the aspect of the membranes. 
CONCLUSIONS. Alternating poly(CTFE-alt-EV) copolymers and poly[(CTFE alt-VE)-co-(HFP-altVE)] terpolymers were synthesized from fluorinated olefins (CTFE, HFP) and vinyl ethers (CEVE, CHVE, BE, and EVE), and were obtained in high yield (>85\%). For the first time, copolymers based on HFP and VE were prepared. Most co- and terpolymers showed a good thermostability $\left(\mathrm{T}_{\mathrm{d}, 10 \%} \geq 300{ }^{\circ} \mathrm{C}\right)$. Though not investigated, these copolymers should have potential application for coatings. Interestingly, the presence of 2-chloroethylvinyl ether (CEVE) in these copolymers enabled, after two consecutive substitutions (NaI then triethylamine), the introduction of ammonium groups in the chains. These copolymers bearing cationic sites are original and susceptible to conduct hydroxide ions. Considering their stability in basic media and their properties, these materials were a good choice as electrode binder for Solid Alkaline Fuel Cells. According to the grafting ratio in ammonium groups, these polyelectrolytes exhibited different solubility. Some of them were water-soluble, while others were not, but all were soluble in organic media and exhibited IEC values ranging from 0.5 meq.g ${ }^{-1}$ to 0.72 meq.g ${ }^{1}$. However, combining the more favorable CEVE content, molecular weight, mechanical properties and hydrophobia, these electrochemical properties should be improved. The assessment of the membraneelectrode assembly performances is currently under progress.

ACKNOWLEDGEMENTS. This work was supported by the Alcapac Project with the French PACo program. By supplying us with free materials, Akzo Nobel and Solvay S.A. companies made this research possible. The authors would like to thank S. Roualdès from the European Institute of Membranes (Montpellier) for her help during the assessment of the electrochemical properties of the membranes, A. Martinent (CEA) as coordinator of the project, as well as Dr Louis Delon and Pr. Bernard Boutevin for fruitful discussions.

\section{Supporting Information.}

\section{Assessment of copolymers composition.}


Thanks to the three signals in the ${ }^{19} \mathrm{~F}$ NMR spectrum centered at $-75.4 \mathrm{ppm}\left(-\mathrm{CF}_{3}\right.$ of HFP), between 109 and -123 ppm (-CF $2^{-}$of CTFE and HFP, $-\mathrm{CF}(\mathrm{Cl})-$ of CTFE) and at -182.7 ppm (-CF(CF 3$)-$ of HFP), the relative composition in CTFE about that of HFP can be obtained from equations (1) and (2).

$$
\% \mathrm{CTFE}=\frac{\left(\int_{-109 \mathrm{ppm}}^{-123 \mathrm{ppm}} \mathrm{CF}_{2}+C \mathrm{FCl}\right)-\frac{2 \times \int_{-75 p p m} C F_{3}}{3}}{\left(\int_{-109 \mathrm{ppm}}^{-123 \mathrm{pm}} \mathrm{CF}_{2}+C \mathrm{FCl}\right)-\frac{\int_{-75 p p m} C F_{3}}{3}}
$$

where $\int_{-i}^{-j}$ represent the integral of the signal ranging from $-\mathrm{i}$ to $-\mathrm{j} \mathrm{ppm}$.

In the ${ }^{1} \mathrm{H}$ NMR spectra, the signals assigned to the $-\mathrm{CH}_{2}$ - and $-\mathrm{CHOR}$ - groups of the main chain, whatever they originate from CEVE, CHVE, EVE, or from BVE, appear between 2.4 and 3.4 ppm and $4.8 \mathrm{ppm}$, respectively. The signals of the pending methylene groups in CEVE are located at $3.7 \mathrm{ppm}$ ($\left.\mathrm{O}-\mathrm{CH}_{2}-\mathrm{CH}_{2}-\mathrm{Cl}\right)$ and $4.1 \mathrm{ppm}\left(-\mathrm{O}-\mathrm{CH}_{2}-\mathrm{CH}_{2}-\mathrm{Cl}\right)$. The methylene protons of cyclohexyl in CHVE yields five peaks centered at 1.3, 1.6, 1.8 and $2.0 \mathrm{ppm}$ while that centered at $3.7 \mathrm{ppm}$ is characteristic of $-\mathrm{CH}<$. The relative composition in CHVE and CEVE units from copolymer P1 (Table 1) was obtained from equations (3) and (4).

$$
\% \mathrm{CEVE}=\frac{\frac{\int_{4.1 \mathrm{ppm}} \mathrm{OCH}_{2}}{2}}{\left(\int_{3.7 \mathrm{ppm}} \mathrm{CH}_{2} \mathrm{Cl}+\mathrm{OCH}\right)-\frac{\int_{4.1 \mathrm{ppm}} \mathrm{OCH}_{2}}{2}}
$$

In the case of P11 terpolymer, the peaks assigned to the alkyl chain of EVE appear at 1.2 ppm (-O$\left.\mathrm{CH}_{2}-\mathrm{CH}_{3}\right)$ and $3.8 \mathrm{ppm}\left(\left(-\mathrm{O}-\mathrm{CH}_{2}-\mathrm{CH}_{3}\right)^{23}\right.$ and the composition in CEVE was obtained from equation (5). 


$$
\% \mathrm{CEVE}=1-\frac{\frac{\int_{1.2 \mathrm{ppm}} \mathrm{CH}_{3}}{3}}{\int_{4.4 \mathrm{ppm}}^{4.8 \mathrm{ppm}} \mathrm{CH}}
$$

For P12 terpolymer, the protons of the butyl group in BVE are represented by four peaks located at 0.9 ppm (-O-CH $\left.-\mathrm{CH}_{2}-\mathrm{CH}_{2}-\mathrm{CH}_{3}\right), 1.4$ ppm $\left(-\mathrm{O}-\mathrm{CH}_{2}-\mathrm{CH}_{2}-\mathrm{CH}_{2}-\mathrm{CH}_{3}\right), 1.6 \mathrm{ppm}\left(-\mathrm{O}-\mathrm{CH}_{2}-\mathrm{CH}_{2}-\mathrm{CH}_{2}-\mathrm{CH}_{3}\right)$ and $3.8 \mathrm{ppm}\left(-\mathrm{O}-\mathrm{CH}_{2}-\mathrm{CH}_{2}-\mathrm{CH}_{2}-\mathrm{CH}_{3}\right)$ and the incorporation of 2-chloroethylvinylether could be determined using equation (6).

$$
\% \mathrm{CEVE}=1-\frac{\frac{\int_{0.9 \mathrm{ppm}} \mathrm{CH}_{3}}{3}}{\int_{4.4 \mathrm{ppm}}^{4.8 \mathrm{pm}} \mathrm{CH}}
$$

In the iodination step, the conversion of the 2-chloroethylvinyl ether into 2-iodoethylvinyl ether was assessed by NMR from the integrals of the proton signals $-\mathrm{CH}_{2}-\mathrm{Cl}$ and $-\mathrm{CH}_{2}-\mathrm{I}$ ( $\delta=3.8$ and $3.4 \mathrm{ppm}$, respectively) and from equation (7).

$$
\alpha_{\mathrm{CEVE}}=\frac{\int_{3.4 \mathrm{ppm}} \mathrm{CH}_{2} \mathrm{I}}{\int_{3.8 \mathrm{ppm}} \mathrm{CH}_{2} \mathrm{I}+\int_{3.8 \mathrm{ppm}} \mathrm{CH}_{2} \mathrm{Cl}}
$$




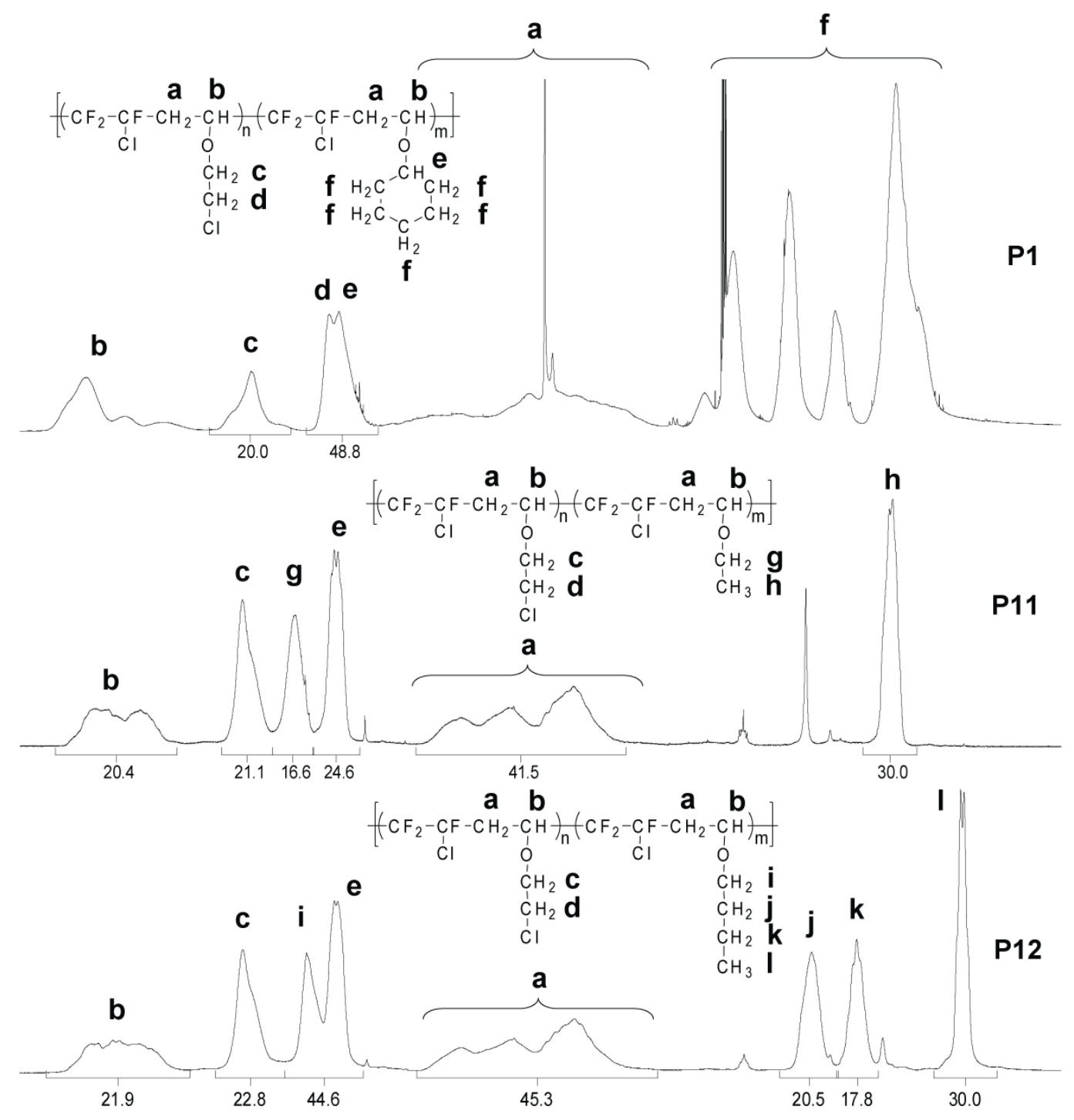

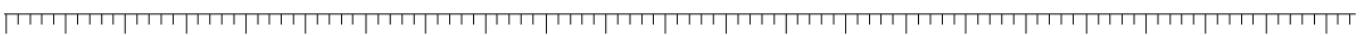

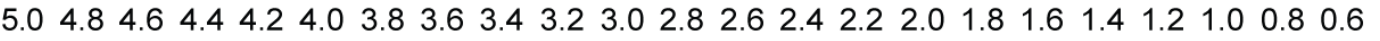

Chemical Shift (ppm)

Figure A. ${ }^{1}$ H NMR spectra of poly[(CTFE-alt-CEVE)-co-(CTFE-alt-CHVE)] (P1), poly[(CTFEalt-CEVE)-co-(CTFE-alt-EVE)] (P11), poly[(CTFE-alt-CEVE)-co-(CTFE-alt-BVE)] (P12) terpolymers in acetone $\mathrm{d}_{6}$, for the first one, and in $\mathrm{CDCl}_{3}$ for the others. (EVE and $\mathrm{BVE}$ stand for ethylvinyl ether and butylvinyl ether, respectively) 


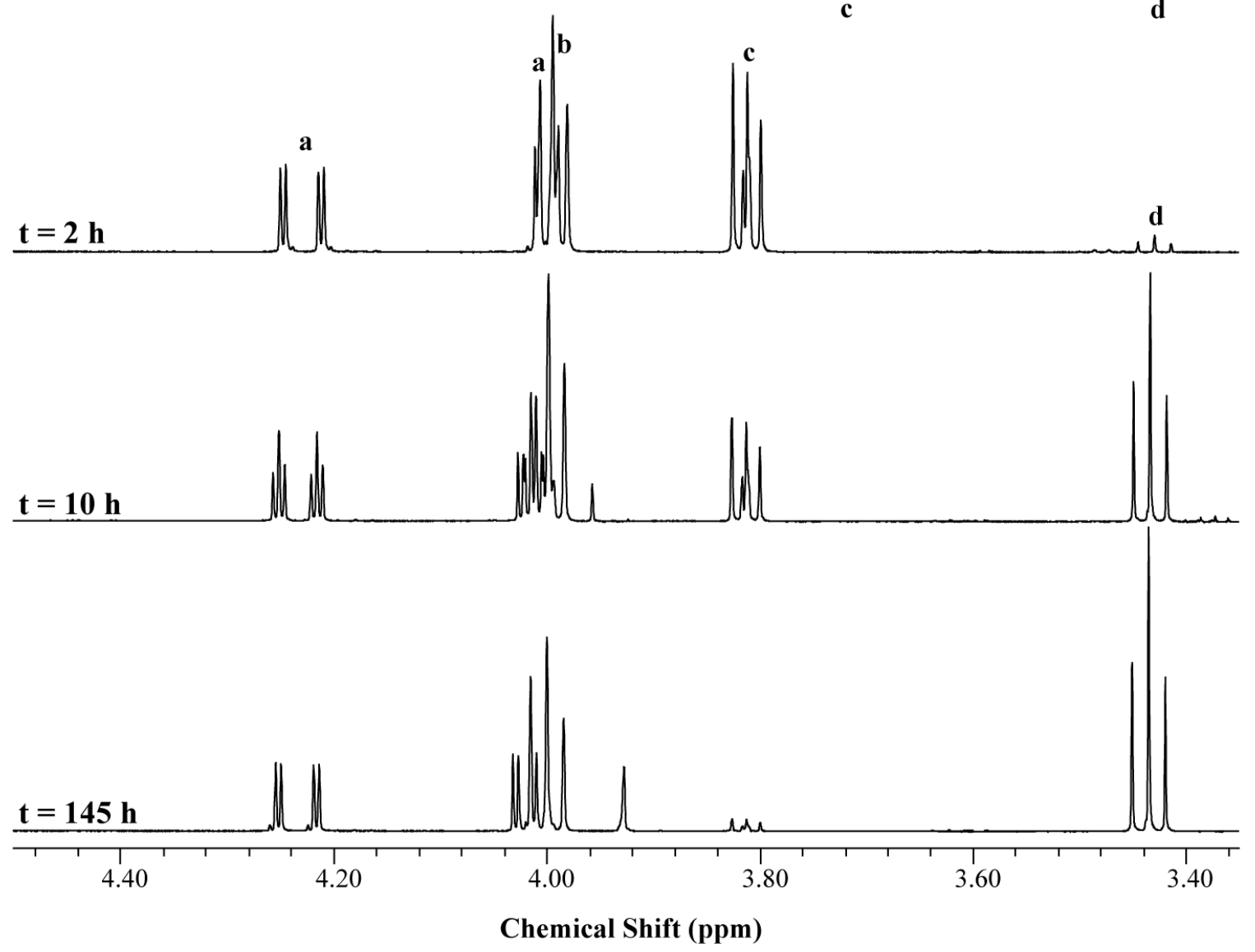

Figure B. ${ }^{1} \mathrm{H}$ NMR spectra of the crude product resulting from the iodination of CEVE at different times $(t=2 \mathrm{~h}, 10 \mathrm{~h}$, and $145 \mathrm{~h})$, at $65^{\circ} \mathrm{C}$ in presence of a 3 fold-excess of NaI, and a concentration in $\mathrm{CEVE}=\mathbf{0 . 2 3 4} \mathrm{M}$. 


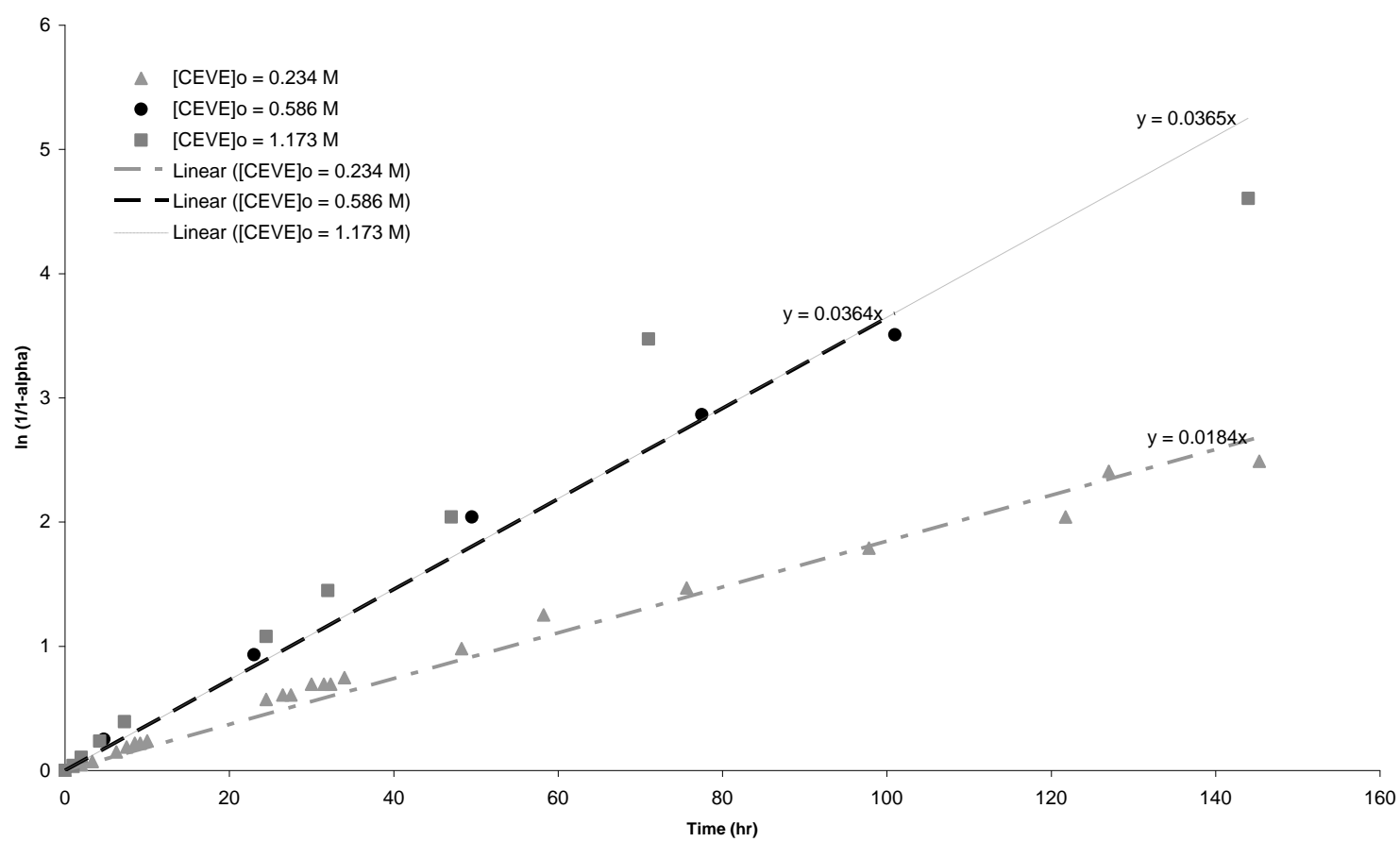

Figure C. Determination of the rate constant $k$ for the iodination of 2-chloroethylvinyl ether (CEVE) monomer into 2-iodoethylvinyl ether (IEVE) from plots of $\operatorname{Ln}(1 / 1-\alpha)$ versus time at different initial CEVE concentration $(\triangle=0.234 \mathrm{M}, \ominus=0.586 \mathrm{M},=1.173 \mathrm{M})$ and where $\alpha$ stands for the CEVE conversion. 


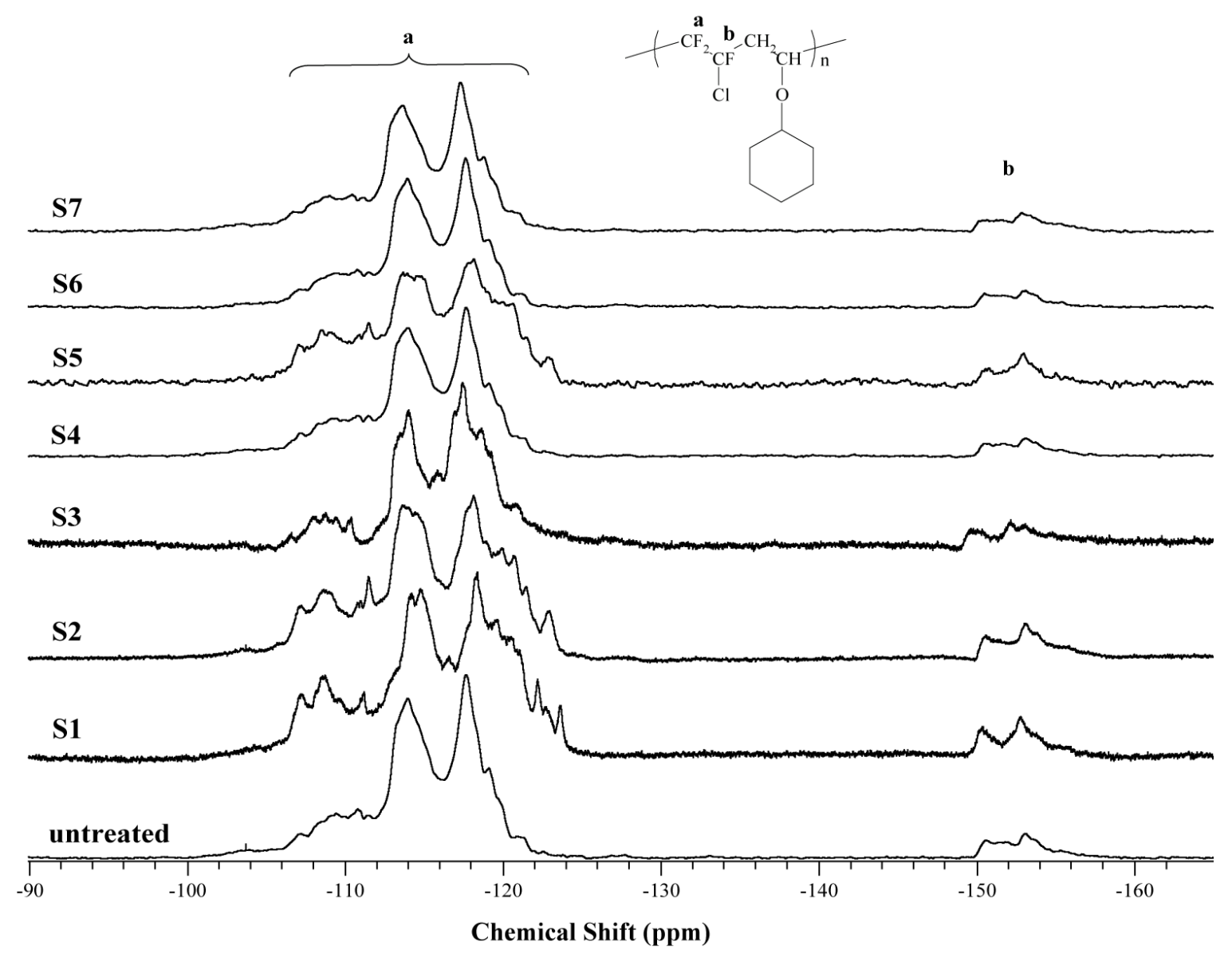

Figure D. ${ }^{19}$ F NMR spectra of the poly(CTFE-alt-CHVE) copolymer (untreated, lower spectra) and exposed to various basic solutions (S1-S7 in Table 4): S1: NaOH (2.5 mol. $\left.\mathrm{L}^{-1}\right) 7$ days; S2: $\mathrm{NaOH}$ (1.25 mol.L $\left.{ }^{-1}\right) 7$ days; S3: $\mathrm{H}_{2} \mathrm{~N}-\left(\mathrm{CH}_{2}\right)_{3}-\mathrm{N}\left(\mathrm{CH}_{3}\right)_{2}(2 \mathrm{eq})+\mathrm{N}\left(\mathrm{CH}_{2} \mathrm{CH}_{3}\right)_{3}(2$ eq) 2.2 days; S4: $\mathrm{N}\left(\mathrm{CH}_{2} \mathrm{CH}_{3}\right)_{3}(3 \mathrm{eq}) 7$ days; S5: $\mathrm{N}\left(\mathrm{CH}_{3}\right)_{3}$ (3 eq) 7 days; S6: $\mathrm{N}\left(\mathrm{CH}_{2} \mathrm{CH}_{3}\right)_{3}$ (3 eq) 3.2 days; S7: HO$\left(\mathrm{CH}_{2}\right)_{2}-\mathrm{SH}(2 \mathrm{eq})+\mathrm{N}\left(\mathrm{CH}_{2} \mathrm{CH}_{3}\right)_{3}(2$ eq $) 7$ days. 


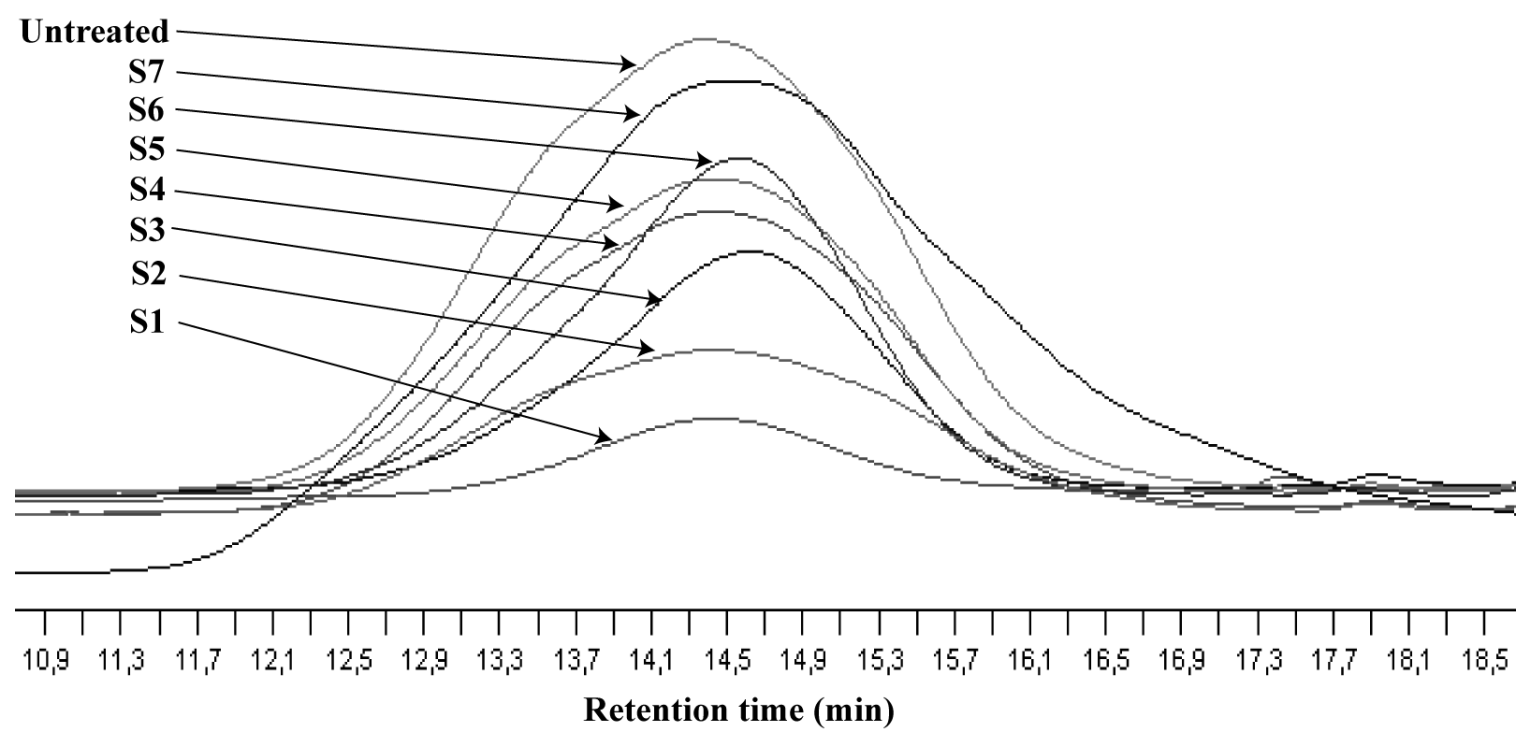

Figure E. Evolution of the SEC chromatogram of the poly(CTFE-alt-CHVE) copolymer (Untreated) exposed to different basic solutions.

This material is available free of charge via the Internet at http://pubs.acs.org.

\section{FIGURE CAPTIONS}

Figure 1. Evolution of the incorporation ratio of chlorotrifluoroethylene (CTFE) versus the cyclohexylvinyl ether (CHVE) conversion during the terpolymerization between CTFE (10 mol.\%), hexafluoropropylene (HFP) (40 mol.\%), and CHVE (50 mol.\%), at $67{ }^{\circ} \mathrm{C}$, initiated by tertbutylperoxypivalate (TBPPi) in $\mathrm{C}_{4} \mathrm{~F}_{5} \mathrm{H}_{5}$.

Figure 2. ${ }^{19} \mathrm{~F}$ NMR spectra of poly(CTFE-alt-CEVE) (P4), poly(HFP-alt-CEVE) (P5), and poly[(CTFEalt-CEVE)-co-(HFP-alt-CEVE)] (P11) copolymers in $\mathrm{CDCl}_{3}$. (CEVE and HFP stand for 2chloroethylvinyl ether and hexafluoropropylene, respectively)

Figure 3. Conversion of 2-chloroethylvinyl ether (CEVE) monomer into 2-iodoethylvinyl ether (IEVE) versus time for different initial CEVE concentrations at $65{ }^{\circ} \mathrm{C}$, in the presence of a 3 fold-excess of NaI with respect to CEVE. 
Figure 4. ${ }^{1} \mathrm{H}$ NMR spectra of the poly(HFP-alt-CEVE) copolymer (P5), iodinated (P5i), and cationized (P5c), in $\mathrm{CDCl}_{3}$ for the first two and in DMSO d6 for the third one.

Figure 5. ${ }^{1} \mathrm{H}$ NMR spectra of the poly(CTFE-alt-CHVE) copolymer (untreated, lower spectrum) and exposed to various basic solutions (S1-S7 in Table 4): S1: $\mathrm{NaOH}\left(2.5\right.$ mol.L $\left.{ }^{-1}\right) 7$ days; $\mathrm{S} 2: \mathrm{NaOH}(1.25$ mol.L $\left.{ }^{-1}\right) 7$ days; S3: $\mathrm{H}_{2} \mathrm{~N}-\left(\mathrm{CH}_{2}\right)_{3}-\mathrm{N}\left(\mathrm{CH}_{3}\right)_{2}(2 \mathrm{eq})+\mathrm{N}\left(\mathrm{CH}_{2} \mathrm{CH}_{3}\right)_{3}\left(2\right.$ eq) 2.2 days; $\mathrm{S} 4: \mathrm{N}\left(\mathrm{CH}_{2} \mathrm{CH}_{3}\right)_{3}(3 \mathrm{eq})$ 7 days; S5: $\mathrm{N}\left(\mathrm{CH}_{3}\right)_{3}$ (3 eq) 7 days; S6: $\mathrm{N}\left(\mathrm{CH}_{2} \mathrm{CH}_{3}\right)_{3}$ (3 eq) 3.2 days; S7: $\mathrm{HO}-\left(\mathrm{CH}_{2}\right)_{2}-\mathrm{SH}(2$ eq) + $\mathrm{N}\left(\mathrm{CH}_{2} \mathrm{CH}_{3}\right)_{3}$ (2 eq) 7 days.

Figure 6. TGA thermograms (under air, at $10{ }^{\circ} \mathrm{C} \cdot \mathrm{min}^{-1}$ ) of the initial (P4) and cationized (P4c) poly(CTFE-alt-CEVE) copolymers, and the original (P1), slightly cationized (P1c1), and highly cationized (P1c2) poly[(CTFE-alt-CHVE)-co-(CTFE-alt-CEVE)] terpolymers.

\section{SCHEME TITLES}

Scheme 1: Radical copolymerization between fluorinated monomers (chlorotrifluoroethylene and hexafluoropropylene) and vinyl ethers.

Scheme 2: Modification of the poly(CTFE-alt-VE) alternating copolymers by iodination, cationization by trimethylamine (TMA), and then counter-ion exchange by sodium hydroxide.

\section{TABLES TITLES.}

Table 1. Experimental conditions and compositions of the poly[(CTFE-alt-VE)-co-(HFP-alt-VE)] terpolymers assessed by elementary analysis, ${ }^{1} \mathrm{H}$ and ${ }^{19} \mathrm{~F}$ NMR spectroscopy.

Table 2. Properties and elemental analysis of poly[(CTFE-alt-VE)-co-(HFP-alt-VE)] terpolymers. 
Table 3. Percentage of substitution of the chlorine atoms into iodine atoms from CEVE in the different poly(CTFE-alt-VE) copolymers after various reaction times.

Table 4. Chemical stability of poly(CTFE-alt-CHVE) alternating copolymers in basic media.

Table 5. Membrane related properties of the different cationized poly[(CTFE-alt-VE)-co-(HFP-altCEVE)] copolymers and a recall of their composition.

\section{REFERENCES}

(1) Varcoe, J. R.; Slade, R. C. T. Fuel Cells 2005, 5 (2), 187-200.

(2) Larminie, J.; Dicks, A., Fuel Cell Explained. 2nd ed.; Wiley: Chichester, England, 2003.

(3) Feiring, A. E., In Organofluorine Chemistry: Principles and Commercial Applications, Banks, R. E.; Smart, B. E.; Tatlow, J. C., Eds. Plenum Press: New York, 1994; Vol. 15, pp 339-372.

(4) Scheirs, J., Modern Fluoropolymers. Wiley: New York, 1997.

(5) Hougham, G.; Cassidy, P. E.; Johns, K.; Davidson, T., Fluoropolymers 2: Properties. Kluwer/ Plenum: New York, 1999.

(6) Ameduri, B.; Boutevin, B., Well-Architectured Fluoropolymers: Synthesis, Properties and Applications. Elsevier: Amsterdam, 2004.

(7) David, G.; Boyer, C.; Tonnar, J.; Ameduri, B.; Lacroix-Desmazes, P.; Boutevin, B. Chem. Rev. 2006, 106 (9), 3936-62.

(8) Banks, B. A., In Modern Fluoropolymers, Scheirs, J., Ed. Wiley\&Sons: New York, 1999; Vol. 4, pp 103-114.

(9) Pawloski, A. R.; La Fontaine, B.; Levinson, H. J.; Hirscher, S.; Schwarzl, S.; Lowack, K.; Kamm, F.-M.; Bender, M.; Domke, W.-D.; Holfeld, C.; Dersch, U.; Naulleau, P.; Letzkus, F.; Butschke, J. Proc. SPIE-Int. Soc. Opt. Eng. 2004, 5567, 762.

(10) Boutevin, B.; Rousseau, A.; Sage, J.-M. US Pat.-2004/097676 (assigned to Total-Fina-Elf).

(11) Iacono, S. T.; Budy, S. M.; Jin, J.; Smith Jr, D. W. J. Polym. Sci., Part A: Polym. Chem. 2007, 45 (24), 5705-21.

(12) Dams, R. J.; Martin, S. J. US Pat.-2005/121644 (assigned to 3M).

(13) Robinson, D.; Seiler, D. A., In National Conference, Linings, Coatings and Materials, Seattle, WA, 1993; Vol. Section 3C, pp 10-14.

(14) Bongiovanni, R.; Malucelli, G.; Pollicino, A.; Tonelli, C.; Simeone, G.; Priola, A. Macromol. Chem. Phys. 1998, 199 (6), 1099-1105.

(15) Sha, J.; Ober, C. K. Polym. Int. 2009, 58 (3), 302-306.

(16) GB-1937/465520 (assigned to I.G. Farbenindustrie A. -G.).

(17) Samuels, G. J.; Shafer, G. J.; Li, T.; Threlfall, C. A.; Iwamoto, N.; Rainal, E. J. WO2008/079986 A1 (assigned to Honeywell International Inc.).

(18) Tabata, Y.; Du Plessis, T. A. J. Polym. Sci., Part A: Polym. Chem. 1971, 9 (12), 3425-35.

(19) Yamabe, M.; Higaki, H.; Kojima, G. Org. Coat. 1984, 16, 25-39.

(20) Munekata, S. Prog. in Org. Coat. 1988, 16 (2), 113-34.

(21) Scheirs, J.; Burks, S.; Locaspi, A. Trends in Polym. Sci. 1995, 3, 74-82.

(22) Yamauchi, M.; Hirono, T.; Kedama, S. I.; Matsuo, M. Eur. Coat. J. 1996, 124-8. 
(23) Takakura, T., CTFE/vinyl ether copolymers. In Modern Fluoropolymers, Scheirs, J., Ed. Wiley Interscience: New York, 1997; Chap. 29, pp 557-64.

(24) Asakawa, A.; Unoki, M.; Hirono, T.; Takayanagi, T. J. Fluorine Chem. 2000, 104 (1), 47-51.

(25) Ichimura, M.; Miyake, H.; Kodama, S.; Hisasue, M. DE-1978/2804262 (assigned to Asahi Glass Co,. Ltd. (Japan)).

(26) Hisasue, M.; Kojima, G.; Kojima, H. Japan-1979/54163985 (assigned to Asahi Glass Co., Ltd. (Japan)).

(27) Munekata, S.; Miyazaki, N.; Kaya, S.; Takayanagi, T. Asahi Garasu-Kenkyu Hokoku 1984, 34, 205-24.

(28) Miyazaki, N.; Takayanagi, T. Asahi Garasu-Kenkyu Hokoku 1986, 36, 155-66.

(29) Nakano, Y.; Miyazaki, H.; Watanabe, K. Japan-1987/62073944 (assigned to Asahi Glass Co., Ltd. (Japan)).

(30) Chandrasekaran, S. Encycl. Polym. Sci. Eng. 1985, 3, 463-80.

(31) Hanford, W. E. US-1940/2392378 (assigned to E.I. du Pont de Nemours \& Co.).

(32) Garbuglio, C.; Ragazzini, M.; Pilati, O.; Carcano, D.; Cevidalli, G. Eur. Polym. J. 1967, 3 (1), 137-44.

(33) Ragazzini, M.; Garbuglio, C.; Carcano, D.; Moinasso, B.; Cevidalli, G. Eur. Polym. J. 1967, 3 (1), 129-36.

(34) Sibilia, J. P.; Roldan, L. G.; Chandrasekaran, S. J. Polym. Sci., Part B: Polym. Phys. 1972, 10 (3), 549-63.

(35) Robertson, A. B. In Poly(ethylene-chlorotrifluoroethylene) fibers, Applied Polymer Symposia, 1973; 1973; pp 89-100.

(36) Khanna, Y. P.; Taylor, T. J.; Chandrasekaran, S. J. Appl. Polym. Sci. 1989, 38 (1), 135-45.

(37) Stanitis, G., ECTFE copolymers. In Modern Fluoropolymers, Scheirs, J., Ed. Wiley Interscience: New York, 1997; Chap. 27, pp 525-539.

(38) Vecellio, M. Prog. in Org. Coat. 2000, 40 (1-4), 225-42.

(39) Lin, S.-C. In Ignition resistance of ECTFE powder coatings, "Fluorine in Coatings V" Conference, Orlando, FL (USA), Jan. 21-22, 2003; Orlando, FL (USA), 2003.

(40) Ragazzini, M.; Carcano, D.; Modena, M.; Serboli, G. C. Eur. Polym. J. 1970, 6 (6), 763-72.

(41) Tabata, Y.; Ishigure, K.; Higaki, H.; Oshima, K. J. Macromol. Sci, Chem. 1970, 4 (4), 801-13.

(42) Ishigure, K.; Tabata, Y.; Oshima, K. J. Macromol. Sci, Chem. 1971, 5 (2), 263-73.

(43) Ishigure, K.; Tabata, Y.; Oshima, K. Macromolecules 1975, 8 (2), 177-81.

(44) Ishigure, K.; Tabata, Y.; Oshima, K. Macromolecules 1970, 3 (1), 27-9.

(45) Carcano, D.; Modena, M.; Ragazzini, M.; Pilati, O. Chim. Actal. 1971, 53, 547-55.

(46) Kostov, G.; Tredwell, M.; Gouverneur, V.; Ameduri, B. J. Polym. Sci., Part A: Polym. Chem. 2007, 45 (17), 3843-50.

(47) Thomas, W. M.; O'Shaughnessy, M. T. J. Polym. Sci. 1953, 11 (5), 455-70.

(48) Murray, D. L.; Harwood, H. J.; Shendy, S. M. M.; Piirma, I. Polymer 1995, 36 (20), 3841-8.

(49) Baradie, B.; Shoichet, M. S. Macromolecules 2002, 35 (9), 3569-75.

(50) Kojima, G.; Yamabe, M. Chem. Abstr. 198563609 1984, 42, 841-9.

(51) Boutevin, B.; Cersosimo, F.; Youssef, B. Macromolecules 1992, 25 (11), 2842-6.

(52) Gaboyard, M.; Hervaud, Y.; Boutevin, B. Polym. Int. 2002, 51 (7), 577-584.

(53) Braun, D.; Elsasser, H.; Hu, F. Eur. Polym. J. 2001, 37 (9), 1779-84.

(54) Reyntjens, W. G. S.; Goethals, E. J. Polym. Adv. Technol. 2001, 12 (1-2), 107-22.

(55) Bartlett, P. D.; Nozaki, K. J. Am. Chem. Soc. 1946, 68 (8), 1495-504.

(56) Butler, G. B.; Chen, J. J. Macromol. Sci, Chem. 1987, 24 (7), 813-28.

(57) Walling, C.; Mayo, F. R. J. Polym. Sci. 1948, 3 (6), 895-7.

(58) Gaylord, N. G.; Stolka, M.; Takahashi, A.; Maiti, S. J. Macromol. Sci, Chem. 1971, 5, 867-81.

(59) Miyamoto, M.; Sawamoto, M.; Higashimura, T. Macromolecules 1984, 17 (3), 265-8.

(60) Lu, Y.; Claude, J.; Zhang, Q.; Wang, Q. Macromolecules 2006, 39 (20), 6962-6968.

(61) Tiers, G. V. D.; Bovey, B. A. J. Polym. Sci. Part A: General Papers 1963, 1 (3), 833-41. 
(62) Pianca, M.; Bonardelli, P.; Tato, M.; Cirillo, G.; Moggi, G. Polymer 1987, 28 (2), 224-30.

(63) Carnevale, d.; Wormald, P.; Ameduri, B.; Tayouo, R.; Ashbrook, S. E. Macromolecules 2009, $42(15), 5652-5659$.

(64) Brown, D. W.; Wall, L. A. J. Polym. Sci., Part A: Polym. Chem. 1968, 6 (5), 1367-79.

(65) Greenley, R. Z., Q and e Values for Free radical Copolymerization of Vinyl Monomers and Telogens. In Polymer Handbook, 4th Edition ed.; Abe, A.; Bloch, D. R.; Immergut, E. H., Eds. Wiley Intersciences: New York, 1999; Vol. II, pp 309-378.

(66) Moggi, G.; Bonardelli, P.; Russo, S. 6th Conv. Ital. Sci. Macromol. 1983, 2, 405-8.

(67) Weise, J. K. Polym. Prep. 1971, 12 (1), 512-520.

(68) Wang, Q.; Fu, S.; Yu, T. Prog. Polym. Sci. 1994, 19 (4), 703-53.

(69) de la Cal, J. C.; Leiza, J. R.; Asua, J. M.; Butte, A.; Storti, G.; Morbidelli, M. Handbook of Polymer Reaction Engineering 2005, 1, 249-322.

(70) Souzy, R.; Ameduri, B.; Boutevin, B. J. Polym. Sci., Part A: Polym. Chem. 2004, 42 (20), $5077-$ 5097.

(71) Souzy, R.; Ameduri, B.; Boutevin, B. Macromol. Chem. Phys. 2004, 205 (4), 476-485.

(72) Boutevin, B.; Cersosimo, F.; Youssef, B.; Kappler, P. J. Fluorine Chem. 1991, 52 (3), 403-18.

(73) Gordon, M.; Taylor, J. S. J. Appl. Chem. 1952, 2, 493-500.

(74) Fox, T. G. Bull. Am. Phys. Soc. 1956, 1, 123-129.

(75) Brown, D. W.; Wall, L. A. J. Polym. Sci., Polym. Phys. Ed. 1969, 7 (4), 601-8.

(76) Johnston, N. W. J. Macromol. Sci., Rev. Macromol. Chem. 1976, C14 (2), 215-50.

(77) Couchman, P. R. Nature 1982, 298 (5876), 729-30.

(78) Schappacher, M.; Deffieux, A. Macromol. Chem., Rapid Commun. 1991, 12 (7), 447-53.

(79) Schappacher, M.; Deffieux, A. Macromolecules 1992, 25 (25), 6744-51.

(80) Bonardelli, P.; Moggi, G.; Turturro, A. Polymer 1986, 17 (6), 905-9.

(81) Gelin, M.-P.; Ameduri, B. J. Fluorine Chem. 2005, 126 (4), 577-85.

(82) Rodriguez, F.; Cohen, C.; Ober, C. K.; Archer, L., Principles of Polymer Systems. 5th ed.; Taylor \& Francis: Routledge, 2006.

(83) Atavin, A. S.; Gusarov, A. V.; Trofimov, B. A.; Nikitin, V. M. Zh. Vses. Khim. O-va. im. 1966, 11, 594-5.

(84) Wanatabe, S.; Hirasa, O. Japan-1992/04046134 (assigned to Kogyo Gijutsuin).

(85) March, J., Advanced Organic Chemistry: Reactions, Mechanisms, and Structure. 6th ed.; Wiley: New York, 2007.

(86) Warshawsky, A.; Kedem, O. J. Membr. Sci. 1990, 53 (1-2), 37-44.

(87) Danks, T. N.; Slade, R. C. T.; Varcoe, J. R. J. Mater. Chem. 2002, 12 (12), 3371-73.

(88) Xu, T.; Zha, F. F. J. Membr. Sci. 2002, 199 (1-2), 203-10.

(89) Danks, T. N.; Slade, R. C. T.; Varcoe, J. R. J. Mater. Chem. 2003, 13 (4), 712-21.

(90) Choi, Y.-J.; Kang, M.-S.; Cho, J.; Moon, S.-H. J. Membr. Sci. 2003, 221 (1-2), 219-31.

(91) Slade, R. C. T.; Varcoe, J. R. Solid State Ionics 2005, 176 (5-6), 585-97.

(92) Kimura, I.; Asakura, J.; Sasao, Y. Asahi Garasu-Kenkyu Hokoku 1995, 44, 61-67.

(93) Brewis, D. M.; Mathieson, I.; Sutherland, I.; Cayless, R. A.; Dahm, R. H. Int. J. Adhes. Adhes. 1996, $16(2), 87-95$.

(94) Hinksman, P.; Isaac, D. H.; Morrissey, P. Polym. Degrad. Stab. 2000, 68 (2), 299-305.

(95) Ross, G. J.; J.F., W.; Hill, M. P.; Morrissey, P. Polymer 2000, 41 (5), 1685.

(96) Mitra, S.; Ghanbari-Siahkali, A.; Kingshott, P.; Almdal, K.; Helle, K. R.; Christensen, A. G. Polym. Degrad. Stab. 2004, 83 (2), 195-206.

(97) Mitra, S.; Ghanbari-Siahkali, A.; Kingshott, P.; Hvilsted, S.; Almdal, K. J. Polym. Sci., Part A: Polym. Chem. 2004, 42 (24), 6216.

(98) Taguet, A.; Sauguet, L.; Ameduri, B.; Boutevin, B. J. Fluorine Chem. 2007, 128 (6), 619-30.

(99) Taguet, A.; Ameduri, B.; Boutevin, B. J. Polym. Sci., Part A: Polym. Chem. 2006, 44, 1855-68.

(100) Handforth, V. Journal of the Oil and Coulour Chemists' Association 1990, 73, 145-8.

(101) Cope, A. C.; Mehta, A. S. J. Am. Chem. Soc. 1963, 85 (13), 1949-52. 


\section{SYNOPSIS TOC}

Co- and ter-polymerization of chlorotrifluoroethylene (CTFE) and/or hexafluoropropylene (HFP) with various vinyl ethers (VEs) led to the formation of alternating polymers endowed with a good thermostability $\left(\mathrm{T}_{\mathrm{d}, 10 \%} \geq 300{ }^{\circ} \mathrm{C}\right)$. Polymers containing 2-chloroethylvinyl ether (CEVE) were modified to obtain cationic materials (ammonium) that were tested as Solid Alkaline Fuel Cell binders. 